\title{
Bisphenol A, nonylphenols, benzophenones, and benzotriazoles in soils, groundwater, surface water, sediments, and food: a review
}

\author{
Alessando Careghini • Andrea Filippo Mastorgio • \\ Sabrina Saponaro • Elena Sezenna
}

Received: 6 October 2014 / Accepted: 8 December 2014 /Published online: 30 December 2014

(C) The Author(s) 2014. This article is published with open access at Springerlink.com

\begin{abstract}
Contaminants of emerging concern (CECs) are not commonly monitored in the environment, but they can enter the environment from a variety of sources. The most worrying consequence of their wide use and environmental diffusion is the increase in the possible exposure pathways for humans. Moreover, knowledge of their behavior in the environment, toxicity, and biological effects is limited or not available for most CECs. The aim of this work is to edit the state of the art on few selected CECs having the potential to enter the soil and aquatic systems and cause adverse effects in humans, wildlife, and the environment: bisphenol A (BPA), nonylphenol (NP), benzophenones (BPs), and benzotriazole (BT). Some reviews are already available on BPA and NP, reporting about their behavior in surface water and sediments, but scarce and scattered information is available about their presence in soil and groundwater. Only a few studies are available about BPs and BT in the environment, in particular in soil and groundwater. This work summarizes the information available in the literature about the incidence and behavior of these compounds in the different environmental matrices and food. In particular, the review focuses on the physical-chemical properties, the environmental fate, the major degradation byproducts, and the environmental evidence of the selected CECs.
\end{abstract}

Keywords Contaminants of emerging concern · Soil . Groundwater $\cdot$ Surface water $\cdot$ Sediments $\cdot$ Food

Responsible editor: Leif Kronberg

A. Careghini - A. F. Mastorgio $\cdot$ S. Saponaro $(\bowtie) \cdot$ E. Sezenna DICA - Sezione Ambientale, Politecnico di Milano, Piazza Leonardo da Vinci 32, 20133 Milan, Italy

e-mail: sabrina.saponaro@polimi.it

\section{Introduction}

Contaminants of emerging concern (CECs) are defined as any synthetic or naturally occurring chemical that is not commonly monitored in the environment, though having the potential to enter soil and aquatic ecosystems and cause adverse effects in humans, wildlife, and the environment. CECs include synthesized and commercialized chemicals that have just gained entry into the environment and a range of chemicals that have been produced and released into the environment for long, for which new concerns (occurrence, fate, adverse effects on human health and the environment) have recently raised (Focazio et al. 2008). CECs include industrial, agricultural, and household chemicals, such as flame retardants and plasticizers, pesticides, gasoline additives, fluorinated compounds and nanomaterials, as well as pharmaceuticals and personal care products, such as human and veterinary antibiotics and drugs, fragrances, sunscreen agents, antimicrobial cleaning agents, and excipients (Daughton and Ternes 1999; Thomaidis et al. 2012; EUGRIS 2013; Molnar et al. 2013; NORMAN 2013).

CECs can enter the environment from a variety of sources, such as industrial wastes, drain from urbanized areas and transportation systems, sewage treatment plants, atmospheric deposition, etc. (Kolpin et al. 2002; Anderson et al. 2012). On agricultural land, field application of biosolids (manure or sludge) and polymers for modern intensive agriculture (i.e., mulch films, drip irrigation tubes, string, clips, pots, etc.) and irrigation with reclaimed water can be significant sources of CECs (Kolpin et al. 2002; Christian et al. 2003; Kumar et al. 2005). Moreover, due to their continuous release into the environment, these contaminants can accumulate and cause adverse effects in ecosystems, as their transformation/removal rate can be exceeded by their high loading rate (Anderson et al. 2012; USEPA 2014a). 
The most worrying consequence of wide use and environmental diffusion of CECs is the increase in the possible exposure pathways for humans, such as ingestion of food plants cultivated on contaminated land or irrigated with reclaimed water, ingestion of meat/animal products from pasture on contaminated land, and consumption of tap water from polluted groundwater or surface water (Weber et al. 2005; Molnar et al. 2013). However, knowledge about the behavior in soil-water systems, toxicity, and biological effects is limited or not available for most CECs; thus, human exposure and related health effects and potential toxicological significance in terrestrial and aquatic ecosystems are mostly unknown and caution is advised. Accordingly, regulatory concentration limits or sound guidance and standard or trigger values for the environmental media have not been established yet (Molnar et al. 2013).

In soil, the behavior of organic contaminants is governed by a variety of complex dynamic physical, chemical, and biological processes, including sorption/desorption, volatilization, leaching, chemical and biological degradation, plant uptake, and runoff (Arias-Estévez et al. 2008). These processes directly control contaminant mobility and fate through the soil and their transfer from soil to water, air, or food. The rate and relative importance of these processes vary with the chemical nature of the contaminant and the chemical, biological, and hydraulic properties of soil (Kibbey et al. 2007). Some compounds, though at trace levels in the sources, accumulate in soils (Kinney et al. 2006; Ternes et al. 2007; Xu et al. 2009), whereas others easily runoff from soil into surface waters or leach to groundwater affecting water reservoirs (Koschorreck et al. 2002). Transport mechanisms related to colloidal material have been underlined for some CECs (Yamamoto and Liljestrand 2003; Zhou et al. 2007).

Most degradation studies were carried out in the aqueous environment (Richardson and Bowron 1985; Buser et al. 1998; Zwiener and Frimmel 2003; Lin and Reinhard 2005; Yu et al. 2006), sewage sludge (Kimura et al. 2007; Zhao et al. 2008), or sediments (Ying and Kookana 2005). Only few studies investigated CEC degradation in soil (Tolls 2001; Gao and Pedersen 2005; Ying and Kookana 2005; Williams and Adamsen 2006; Chefetz et al. 2008; Xuan et al. 2008), showing that some organic contaminants are biodegradable at a certain extent, whereas others exhibit very slow biodegradation rates or are sequestered within soil particles, being inaccessible for microbial degradation. Moreover, most of the previous studies on soil focused on sorption/desorption at equilibrium conditions and degradation under optimal conditions in batch tests, instead of assessing transport dynamics under field conditions (Wehrhan et al. 2007).

The aim of this work is to edit the state of the art on few selected contaminants of emerging concern (bisphenol A, nonylphenol, benzophenones, and benzotriazole) that have been already measured in many European environmental samples and belong to different classes of widely used emerging substances (plasticizers, surfactants, personal care products, and industrial chemicals) (EUGRIS 2013; Molnar et al. 2013; NORMAN 2013). In particular, the review focuses on their physical-chemical properties in relation with their environmental fate and transport, major degradation byproducts, and environmental evidence.

\section{Bisphenol A (BPA)}

Bisphenol A (2,2-bis(4-hydroxyphenyl)propane) is an organic compound composed of two phenol molecules bonded by a methyl bridge and two methyl groups (Table 1).

BPA is used as an intermediate (binding, plasticizing, and hardening) in plastics, paints/lacquers, binding materials, and filling materials. Furthermore, it is used as an additive for flame-retardants, brake fluids, and thermal papers. About $95 \%$ of BPA produced in industry is used to make plastics, in particular polycarbonate resins (71\%) and epoxy resins (29\%) (RIKZ 2001; Huang et al. 2012). Due to the increasing demand for polycarbonates and epoxy resins, BPA production has constantly grown in the last years: the global demand was $3.2,3.9$, and 5.0 million tons in 2003, 2006, and 2010, respectively (Flint et al. 2012; Huang et al. 2012).

\section{Toxicity}

BPA is listed as an endocrine disrupter. It has been proven to have estrogenic activity even at concentrations below $1 \mu \mathrm{g} / \mathrm{m}^{3}$ (Rykowska and Wasiak 2006). Estrogenic compounds can have deleterious effects on living organisms because they can disrupt natural hormone balance in both men and women. The effects of exposure to BPA can be particularly harmful to fetus, infants, and young children, because of lack of feedback regulating the activity, synthesis, and elimination of hormones (RIKZ 2001; Rykowska and Wasiak 2006). The acute toxicity of BPA is relatively low. In subacute toxicity studies, a marked reduction in the rate of body weight increase was observed in treated animals (RIKZ 2001). There is limited evidence for carcinogenicity in animals; according to the IARC classification, BPA belongs to group 3 ("not classifiable as to its carcinogenicity to humans") (IARC 1999).

Ingestion through contaminated food is the major exposure pathway for humans; inhalation and dermal contact are significant exposure pathways for workers involved in the manufacture of BPA. Rykowska and Wasiak (2006) recommended a reference dose (RfD) for oral exposure of $0.01 \mathrm{mg} / \mathrm{kg} /$ day. USEPA estimated a reference dose of $50 \mu \mathrm{g}$ of BPA $/ \mathrm{kg}$ of body weight/day (USEPA-IRIS 2014). 
Table 1 List of chemical compounds studied in the paper

\begin{tabular}{|l|c|c|c|c|}
\hline Compound & CAS number & Formula & & \\
\hline Bisphenol A (BPA) & $80-05-7$ & $\mathrm{C}_{15} \mathrm{H}_{16} \mathrm{O}_{2}$ \\
\hline Nonylphenol (NP) & $104-40-5$ & $\mathrm{C}_{15} \mathrm{H}_{24} \mathrm{O}$ & \\
\hline Benzophenone (BP) & $119-61-9$ & $\mathrm{C}_{13} \mathrm{H}_{10} \mathrm{O}$ & \\
\hline Benzophenone-3 (BP-3) & $131-57-7$ & $\mathrm{C}_{14} \mathrm{H}_{12} \mathrm{O}_{3}$
\end{tabular}

\section{Environmental fate and transport}

BPA is not produced naturally; it can be released into the environment during production and transport operations, from many products during their use or after their disposal in landfill, through effluent from wastewater treatment plants and from sewage sludge used in agriculture (Huang et al. 2012).

BPA is a moderately water-soluble compound at ambient temperature (Table 2). It has low vapor pressure and does not tend to volatilize significantly from water or dry soil surfaces (Flint et al. 2012). Based on the organic carbon/water partition coefficient $\left(K_{\mathrm{OC}}\right)$ value, significant sorption of BPA on soil and sediments is expected. Based on the octanol/water partition coefficient $K_{\mathrm{OW}}$, BPA has modest capacity for bioaccumulation, which occurs only at high doses (Fent et al. 2003; Flint et al. 2012; Roberts et al. 2014).

Hydrolysis is expected to be negligible under environmental conditions due to the absence of hydrolysable groups, but BPA not tied to organic matter undergoes photolysis in water at wavelengths above $290 \mathrm{~nm}$ (RIKZ 2001). Pseudo-firstorder degradation constants between 0.0053 and $0.008 \mathrm{l} / \mathrm{min}$ were observed in aqueous solutions with $10 \mathrm{~g} / \mathrm{m}^{3}$ of humic substances and BPA between 1 and $20 \mathrm{~g} / \mathrm{m}^{3}$; no photodegradation occurred in pure water (Zhan et al. 2006).

BPA can be readily biodegraded in soil and sediments under aerobic conditions, with estimated half-life values in soils between 3 and 37.5 days. No degradation was observed in anaerobic soils during 70 day experiments or in anoxic estuarine sediments during 120 day experiments (RIKZ 2001; Fent et al. 2003; Flint et al. 2012; Yu et al. 2013; Chang et al. 2014; Yang et al. 2014). BPA is not expected to be persistent in the environment (USEPA 2010a; Michałowicz 2014).

Degradation byproducts

Many bacterial strains capable of growing on BPA as a sole source of carbon and energy were isolated from different environmental matrices; they included both gram-negative and gram-positive strains (Zhang et al. 2013a). Different degradation pathways for BPA have been proposed in the literature. In particular, biodegradation of BPA proceeds via complicated metabolic routes that leads to formation of several kinds of byproducts (Spivack et al. 1994; Ike et al. 2002; Zhan et al. 2006; Ye et al. 2011).

Zhan et al. (2006) proposed a photodegradation pathway in aqueous solution with humic substances based on the results of structural analyses for intermediate photoproducts. Monohydroxylated BPA, glycerol, 2-hydroxy-propanoic acid, and $p$-hydroquinone were identified as degradation products.

Zhang et al. (2007) studied BPA degradation by a microbial strain isolated from the compost leachate of a municipal solid waste; 4-hydroxybenzaldehyde, 4-hydroxybenzoic acid, and 


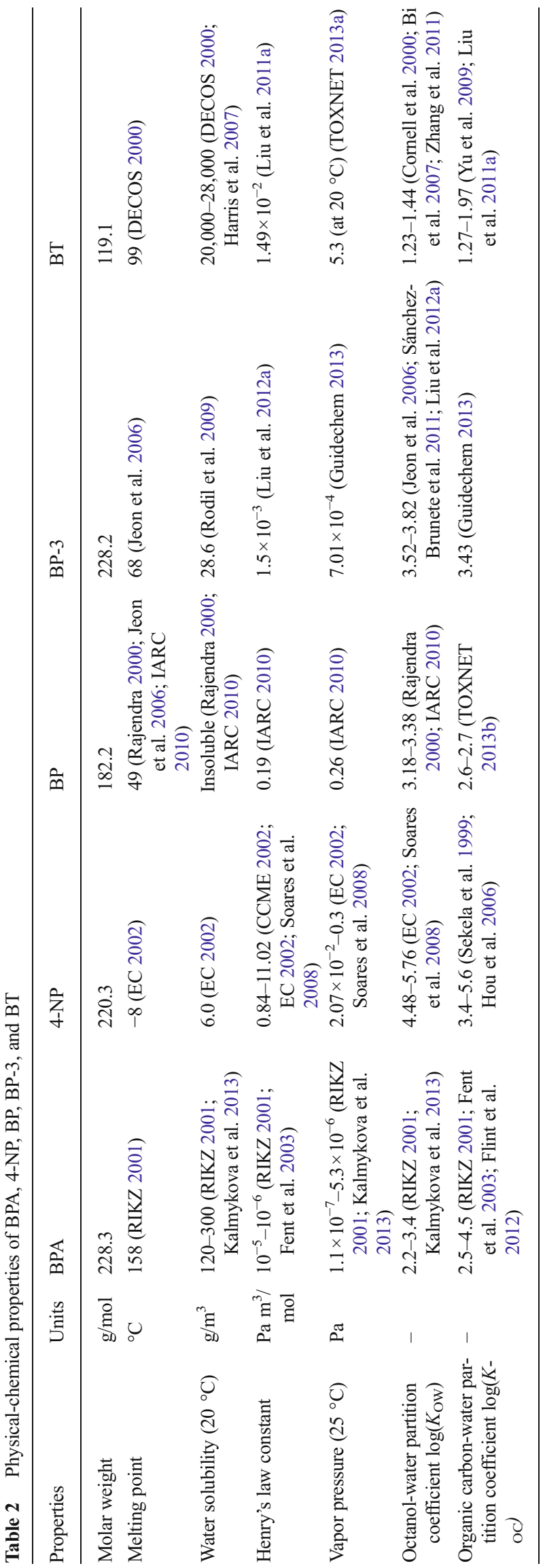

$p$-hydroquinone were the observed metabolic intermediates. Also, Dodgen et al. (2014) detected 4-hydroxybenzaldehyde and 4-hydroxybenzoic acid, together with 4hydroxyacetophenone, as transformation products of BPA in degradation tests using different artificially contaminated soils.

Spivack et al. (1994) studied the degradation pathway for a gram-negative aerobic bacterium (pure culture). The major route $(80 \%)$ was BPA cleavage to $p$-hydroxyacetophenone ( $p$-HAP) and $p$-hydroxybenzaldehyde ( $p$-HBAL), followed by further degradation via $p$-hydroxybenzoic acid ( $p$-HBA). The remaining $20 \%$ of BPA was converted into 2,3-bis-(4hydroxyphenyl)-1,2-propanediol (tetraol-IV) via bis(4hydroxyphenyl)-1-propanol. Although tetraol-IV can be slowly degraded to $p$-hydroxyphenacyl alcohol ( $p-\mathrm{HPOH})$, both these byproducts accumulated in the medium. In Ike et al. (2002), BPA degradation by mixed microbial consortia from activated sludge or river water also led in most cases to the accumulation of the minor route byproducts tetraol-IV and $p$ $\mathrm{HPOH}$, generally identified as the dead-end compounds. Based on the studies reported above, BPA photodegradation and biodegradation do not seem to mineralize the compound.

Ye et al. (2011) investigated BPA metabolism in rat and human liver microsomes. The oxidative metabolism of BPA to BPA catechol was a major pathway when using male rat microsomes, but only a minor pathway (less than $10 \%$ BPA catechol was formed) when using human liver microsomes.

\section{Environmental evidence}

The major studies reported in the literature about BPA presence in environmental matrices and food are reported in Table 3. Industrial activities (mainly chemical plants) and wastewater treatment plants were the major sources of BPA in the surface waters and sediments. High concentrations in soil and groundwater were detected especially for agricultural fields irrigated with treated wastewater and/or amended with biosolids or near landfills (Heemken et al. 2001; Kawahata et al. 2004; Cespedes et al. 2005; Vethaak et al. 2005; Loos et al. 2007; Yoon et al. 2010; Félix-Cañedo et al. 2013; Wu et al. 2013; Gorga et al. 2014; Michałowicz 2014).

\section{$B P A$ in soil and sediments}

BPA concentrations in soils span between 0.55 and $147 \mu \mathrm{g} / \mathrm{kg}$ on dry weight basis (d.w.), with higher values generally found in agricultural fields amended with biosolids or irrigated with wastewater. Kinney et al. (2008) observed higher maximum concentrations of BPA in soils at a not-amended site $(147 \mu \mathrm{g} /$ $\mathrm{kg}$ d.w.) than at a site amended with biosolids ( $81 \mu \mathrm{g} / \mathrm{kg} \mathrm{d.w.})$; no detectable concentration of BPA was observed in site receiving liquid swine manure. Low values were observed by $\mathrm{Xu}$ et al. (2008) in soils from a golf course in southern 
Table 3 BPA concentrations in various environmental matrices and in food (percentages between brackets represent the detection frequency)

\begin{tabular}{|c|c|c|c|}
\hline Reference & Location & Units & Value \\
\hline \multicolumn{4}{|l|}{ Soils } \\
\hline Kinney et al. (2008) & Agricultural fields, USA & $\mu \mathrm{g} / \mathrm{kg}$ d.w. & $\begin{array}{l}<32-147 \\
\text { Mean } 59\end{array}$ \\
\hline Xu et al. (2008) & $\begin{array}{l}\text { Golf course irrigated with reclaimed wastewater, } \\
\text { California, USA }\end{array}$ & $\mu \mathrm{g} / \mathrm{kg}$ d.w. & $0.55-2$ \\
\hline Gibson et al. (2010) & $\begin{array}{l}\text { Agricultural fields irrigated with } \\
\text { wastewater, Tula Valley, Mexico }\end{array}$ & $\mu \mathrm{g} / \mathrm{kg}$ d.w. & $\begin{array}{l}1.6-30.2 \\
\text { Mean } 8.3\end{array}$ \\
\hline Staples et al. (2010) & $\begin{array}{l}\text { Soils amended with biosolids, North America } \\
\text { (data collected in the period 1990-2006) }\end{array}$ & $\mu \mathrm{g} / \mathrm{kg}$ d.w. & $\begin{array}{l}\text { Median } 1.15 \\
\text { 95th percentile } 21\end{array}$ \\
\hline Staples et al. (2010) & $\begin{array}{l}\text { Soils amended with biosolids, Europe (data collected } \\
\text { in the period 1990-2006) }\end{array}$ & $\mu \mathrm{g} / \mathrm{kg}$ d.w. & $\begin{array}{l}\text { Median } 0.24 \\
\text { 95th percentile } 140\end{array}$ \\
\hline USEPA (2010a) & Range of values in USA & $\mu \mathrm{g} / \mathrm{kg}$ d.w. & $\begin{array}{l}4-14 \\
\text { Mean 6-7 }\end{array}$ \\
\hline \multicolumn{4}{|l|}{ Sediments } \\
\hline Heemken et al. (2001) & Elbe River and some of its tributaries, Germany & $\mu \mathrm{g} / \mathrm{kg}$ d.w. & $\begin{array}{l}66-343 \\
\text { Mean } 163\end{array}$ \\
\hline Kawahata et al. (2004) & $\begin{array}{l}\text { Estuarine and marine sediments from Okinawa and } \\
\text { Ishigaki Islands, Japan }\end{array}$ & $\mu \mathrm{g} / \mathrm{kg}$ d.w. & $\begin{array}{l}<0.5-13 \\
\text { Mean } 3.2\end{array}$ \\
\hline Vethaak et al. (2005) & Fresh, marine, and estuarine sediments, The Netherlands & $\mu \mathrm{g} / \mathrm{kg}$ d.w. & $\begin{array}{l}<1.1-43 \\
\text { Median } 3.2(78 \%)\end{array}$ \\
\hline Fu et al. (2007) & $\begin{array}{l}\text { Estuarine and marine sediments from Jiaozhou Bay } \\
\text { and surrounding rivers, China }\end{array}$ & $\mu \mathrm{g} / \mathrm{kg}$ d.w. & $0.7-27.3$ \\
\hline Pojana et al. (2007) & Sediments from Venice Lagoon, Italy & $\mu \mathrm{g} / \mathrm{kg}$ d.w. & $\begin{array}{l}<2.0-118 \\
\text { Mean } 36\end{array}$ \\
\hline USEPA (2010a) & Fresh sediments, USA & $\mu \mathrm{g} / \mathrm{kg}$ d.w. & $1.4-140$ \\
\hline USEPA (2010a) & Marine sediments, USA & $\mu \mathrm{g} / \mathrm{kg}$ d.w. & $1.5-5.0$ \\
\hline Gorga et al. (2014) & Ebro River basin, Spain & $\mu \mathrm{g} / \mathrm{kg}$ d.w. & $<0.24-100$ \\
\hline Michałowicz (2014) & Elba River sediments, Germany & $\mu \mathrm{g} / \mathrm{kg}$ d.w. & $10-380$ \\
\hline Michałowicz (2014) & 16 major rivers' sediments, Taiwan & $\mu \mathrm{g} / \mathrm{kg}$ d.w. & $0.37-492$ \\
\hline Stewart et al. (2014) & Estuarine sediments from Auckland, New Zealand & $\mu \mathrm{g} / \mathrm{kg}$ d.w. & $\begin{array}{l}<50-145 \\
\text { Mean } 57\end{array}$ \\
\hline Wu et al. (2013) & Huangpu River and its tributaries, China & $\mu \mathrm{g} / \mathrm{kg}$ d.w. & $\begin{array}{l}0.96-14.44 \\
\text { Mean } 7.22\end{array}$ \\
\hline Gorga et al. (2015) & Different rivers, Spain & $\mu \mathrm{g} / \mathrm{kg}$ d.w. & $<0.24-117$ \\
\hline \multicolumn{4}{|l|}{ Groundwater } \\
\hline Lacorte et al. (2002) & Agricultural area in Catalonia, Spain & $\mathrm{mg} / \mathrm{m}^{3}$ & $<0.01-0.35$ \\
\hline Latorre et al. (2003) & Agricultural areas in northern Spain & $\mathrm{mg} / \mathrm{m}^{3}$ & $0.05-0.18$ \\
\hline Godejohann et al. (2009) & Ammunition disposal site, Switzerland & $\mathrm{mg} / \mathrm{m}^{3}$ & $12-13$ \\
\hline Loos et al. (2010) & Survey on European groundwaters & $\mathrm{mg} / \mathrm{m}^{3}$ & $\begin{array}{l}<0.001-2.299 \\
\text { Mean } 0.079 \\
\text { 90th percentile } 0.073\end{array}$ \\
\hline USEPA (2010a) & Range of mean values in USA & $\mathrm{mg} / \mathrm{m}^{3}$ & $0.004-1.9$ \\
\hline Stuart et al. (2011) & Groundwater, England & $\mathrm{mg} / \mathrm{m}^{3}$ & up to 20 \\
\hline Félix-Cañedo et al. (2013) & Groundwater in Mexico City, Mexico & $\mathrm{mg} / \mathrm{m}^{3}$ & $<0.0005-0.010(63 \%)$ \\
\hline Luo et al. (2014) & Groundwater in Europe & $\mathrm{mg} / \mathrm{m}^{3}$ & Mean 0.079 , maximum 2.299 \\
\hline Luo et al. (2014) & Groundwater in USA & $\mathrm{mg} / \mathrm{m}^{3}$ & Mean 2.550 \\
\hline Michałowicz (2014) & $\begin{array}{l}\text { Groundwater contaminated with leachate from } \\
\text { refuse dump in Osaka, Japan }\end{array}$ & $\mathrm{mg} / \mathrm{m}^{3}$ & 740 \\
\hline \multicolumn{4}{|l|}{ Surface water } \\
\hline Azevedo et al. (2001) & River and coastal waters, Portugal & $\mathrm{mg} / \mathrm{m}^{3}$ & $\begin{array}{l}0.07-4.0 \\
\text { Mean } 1.0\end{array}$ \\
\hline Heemken et al. (2001) & Elbe River and some of its tributaries, Germany & $\mathrm{mg} / \mathrm{m}^{3}$ & $\begin{array}{l}0.017-0.776 \\
\text { Mean } 0.105\end{array}$ \\
\hline
\end{tabular}


Table 3 (continued)

\begin{tabular}{|c|c|c|c|}
\hline Reference & Location & Units & Value \\
\hline Basheer et al. (2004) & Surface coastal water, Singapore & $\mathrm{mg} / \mathrm{m}^{3}$ & $\begin{array}{l}<0.002-2.47 \\
\text { Mean } 0.40\end{array}$ \\
\hline Kawahata et al. (2004) & $\begin{array}{l}\text { Estuarine and marine waters from } \\
\text { Okinawa, and Ishigaki Islands, Japan }\end{array}$ & $\mathrm{mg} / \mathrm{m}^{3}$ & $\begin{array}{l}<0.005-0.08 \\
\text { Mean } 0.02\end{array}$ \\
\hline Cespedes et al. (2005) & Llobregat River basin, Spain & $\mathrm{mg} / \mathrm{m}^{3}$ & $\begin{array}{l}<0.09-2.97 \\
\text { Mean } 0.44\end{array}$ \\
\hline Vethaak et al. (2005) & Fresh, marine and estuarine water, The Netherlands & $\mathrm{mg} / \mathrm{m}^{3}$ & $\begin{array}{l}<0.009-1.0 \\
\text { Median } 0.045(52 \%)\end{array}$ \\
\hline Patrolecco et al. (2006) & Tiber River, Italy & $\mathrm{mg} / \mathrm{m}^{3}$ & $\begin{array}{l}<0.03-0.14 \\
\text { Mean } 0.07\end{array}$ \\
\hline Vousta et al. (2006) & Glatt River, Switzerland & $\mathrm{mg} / \mathrm{m}^{3}$ & $0.009-0.076$ \\
\hline Fu et al. (2007) & Estuarine and marine water from Jiaozhou Bay, China & $\mathrm{mg} / \mathrm{m}^{3}$ & $0.0015-0.262$ \\
\hline Loos et al. (2007) & River water, Belgium & $\mathrm{mg} / \mathrm{m}^{3}$ & $\begin{array}{l}0.003-0.055 \\
\text { Mean } 0.031\end{array}$ \\
\hline Loos et al. (2007) & River water, Italy & $\mathrm{mg} / \mathrm{m}^{3}$ & $\begin{array}{l}<0.002-0.175 \\
\text { Mean } 0.065\end{array}$ \\
\hline Pojana et al. (2007) & Venice Lagoon, Italy & $\mathrm{mg} / \mathrm{m}^{3}$ & $\begin{array}{l}<0.001-0.145 \\
\text { Mean } 0.014\end{array}$ \\
\hline Yoon et al. (2010) & Han River, South Korea & $\mathrm{mg} / \mathrm{m}^{3}$ & $\begin{array}{l}0.0069-0.059 \\
\text { Mean } 0.027\end{array}$ \\
\hline Yoon et al. (2010) & $\begin{array}{l}\text { Effluent-dominated creeks discharging into Han } \\
\text { River, South Korea }\end{array}$ & $\mathrm{mg} / \mathrm{m}^{3}$ & $\begin{array}{l}0.011-0.120 \\
\text { Mean } 0.062\end{array}$ \\
\hline USEPA (2010a) & Range of mean values in USA & $\mathrm{mg} / \mathrm{m}^{3}$ & $0.012-0.14$ \\
\hline Félix-Cañedo et al. (2013) & Surface water (dams) in Mexico City, Mexico & $\mathrm{mg} / \mathrm{m}^{3}$ & $<0.0005-0.007(52 \%)$ \\
\hline Esteban et al. (2014) & Manzanares and Jarama rivers, Spain & $\mathrm{mg} / \mathrm{m}^{3}$ & $0.006-0.126$ \\
\hline Luo et al. (2014) & Canada & $\mathrm{mg} / \mathrm{m}^{3}$ & $\begin{array}{l}\text { Mean } 0.0021 \\
\text { Maximum } 0.087\end{array}$ \\
\hline Luo et al. (2014) & China & $\mathrm{mg} / \mathrm{m}^{3}$ & $0.006-0.881$ \\
\hline Luo et al. (2014) & Germany & $\mathrm{mg} / \mathrm{m}^{3}$ & $0.192-0.215$ \\
\hline Luo et al. (2014) & Greece & $\mathrm{mg} / \mathrm{m}^{3}$ & $0.055-0.152$ \\
\hline Luo et al. (2014) & Korea & $\mathrm{mg} / \mathrm{m}^{3}$ & $0.0075-0.334$ \\
\hline Luo et al. (2014) & UK & $\mathrm{mg} / \mathrm{m}^{3}$ & $0.006-0.068$ \\
\hline Michałowicz (2014) & Range of concentrations in rivers, Portugal & $\mathrm{mg} / \mathrm{m}^{3}$ & $0.029-0.098$ \\
\hline Melo and Brito (2014) & Rivers crossing Sao Luis island, Brazil & $\mathrm{mg} / \mathrm{m}^{3}$ & $<0.46$ \\
\hline Michałowicz (2014) & Elba River, Germany & $\mathrm{mg} / \mathrm{m}^{3}$ & 4-92 \\
\hline Michałowicz (2014) & 16 major rivers, Taiwan & $\mathrm{mg} / \mathrm{m}^{3}$ & $0.01-45$ \\
\hline Wu et al. (2014) & Huangpu River and its tributaries, China & $\mathrm{mg} / \mathrm{m}^{3}$ & $\begin{array}{l}0.0071-0.1115 \\
\text { Mean } 0.0276\end{array}$ \\
\hline Xu et al. (2014) & Cape D’ Aguilar Marine Reserve, Hong Kong, wet season & $\mathrm{mg} / \mathrm{m}^{3}$ & $0.011-0.41$ Mean 0.0645 \\
\hline Xu et al. (2014) & Cape D’ Aguilar Marine Reserve, Hong Kong, dry season & $\mathrm{mg} / \mathrm{m}^{3}$ & $\begin{array}{l}0.025-0.24 \\
\text { Mean } 0.0695\end{array}$ \\
\hline Zhang et al. (2014) & North Tai Lake Basin, Eastern China & $\mathrm{mg} / \mathrm{m}^{3}$ & $\begin{array}{l}0.024-1.175 \\
\text { Mean } 0.270\end{array}$ \\
\hline Gorga et al. (2015) & Iberian rivers (Ebro, Llobregat, Júcar and Guadalquivir) & $\mathrm{mg} / \mathrm{m}^{3}$ & $0.00011-0.649$ \\
\hline \multicolumn{4}{|l|}{ Food } \\
\hline Basheer et al. (2004) & Seafood from supermarkets, Singapore & $\mu \mathrm{g} / \mathrm{kg}$ f.w. & $\begin{array}{l}13.3-213.1 \\
\text { Mean } 82.5\end{array}$ \\
\hline Sun et al. (2006) & $\begin{array}{l}\text { Canned vegetables, fruits, and meats from local } \\
\text { supermarkets, Singapore }\end{array}$ & $\mu \mathrm{g} / \mathrm{kg}$ f.w. & $\begin{array}{l}32.8-164.5 \\
\text { Mean } 72.5\end{array}$ \\
\hline Isobe et al. (2007) & $\begin{array}{l}\text { Green mussel from India, Indonesia, Singapore, Malaysia, } \\
\text { Thailand, Cambodia, Vietnam, and the Philippines } \\
\text { during 1994-1999 }\end{array}$ & $\mu \mathrm{g} / \mathrm{kg}$ d.w. & $1.1-13.7$ \\
\hline Isobe et al. (2007) & Tokyo Bay & $\mu \mathrm{g} / \mathrm{kg}$ d.w. & $0.54-13.4$ \\
\hline
\end{tabular}


Table 3 (continued)

\begin{tabular}{|c|c|c|c|}
\hline Reference & Location & Units & Value \\
\hline Shao et al. (2007) & Meat/seafood from supermarkets in Beijing, China & $\mu \mathrm{g} / \mathrm{kg}$ f.w. & $\begin{array}{l}<0.30-7.08 \\
\text { Mean } 0.71\end{array}$ \\
\hline Cao et al. (2011) & Different foods from stores in Quebec City, Canada & $\mu \mathrm{g} / \mathrm{kg}$ f.w. & $\begin{array}{l}0.2-106 \\
\text { Mean } 7.7\end{array}$ \\
\hline Noonan et al. (2011) & $\begin{array}{l}\text { Canned food from local supermarkets in Washington } \\
\text { and Maryland, USA }\end{array}$ & $\mu \mathrm{g} / \mathrm{kg}$ f.w. & $\begin{array}{l}<2-790 \\
\text { Mean } 509\end{array}$ \\
\hline Gyllenhammar et al. (2012) & Fruits, meats, and vegetables commercially available, Sweden & $\mu \mathrm{g} / \mathrm{kg}$ f.w. & $\begin{array}{l}<2.0-29.0 \\
\text { Mean } 3.8\end{array}$ \\
\hline Dodgen et al. (2013) & Lettuce and collards, steam and leaves & $\mu \mathrm{g} / \mathrm{kg}$ f.w. & $0.22-3.05$ \\
\hline Dodgen et al. (2013) & Lettuce and collards, roots & $\mu \mathrm{g} / \mathrm{kg}$ f.w. & $199.6-441.7$ \\
\hline Li et al. (2013c) & Soft commercial drinks & $\mathrm{mg} / \mathrm{m}^{3}$ & $\begin{array}{l}<0.02-0.86 \\
\text { Mean } 0.31\end{array}$ \\
\hline Lu et al. (2013) & Vegetables and fruits in Florida, USA & $\mu \mathrm{g} / \mathrm{kg}$ f.w. & $\begin{array}{l}0.2-9.0 \\
\text { Mean } 4.2\end{array}$ \\
\hline Maggioni et al. (2013) & Drinking water from public drinking fountains, Italy & $\mathrm{mg} / \mathrm{m}^{3}$ & $<0.00073-0.102$ \\
\hline Maggioni et al. (2013) & Bottled mineral water, Italy & $\mathrm{mg} / \mathrm{m}^{3}$ & $<0.00073-0.00113$ \\
\hline Michałowicz (2014) & Meat products, worldwide & $\mu \mathrm{g} / \mathrm{kg}$ f.w. & $0.49-56$ \\
\hline Michałowicz (2014) & Fish, worldwide & $\mu \mathrm{g} / \mathrm{kg}$ f.w. & $7.1-103$ \\
\hline Michałowicz (2014) & Vegetables and fruits, worldwide & $\mu \mathrm{g} / \mathrm{kg}$ f.w. & $11-95$ \\
\hline Michałowicz (2014) & Cereals, worldwide & $\mu \mathrm{g} / \mathrm{kg}$ f.w. & $1.0-3.8$ \\
\hline Michałowicz (2014) & $\begin{array}{l}\text { Various tinned products, including } \\
\text { vegetables, fruits, and seafood, worldwide }\end{array}$ & $\mu \mathrm{g} / \mathrm{kg}$ f.w. & $0.1-267$ \\
\hline
\end{tabular}

California irrigated with reclaimed wastewater, but the authors pointed out the potential exposition of groundwater to contamination due to the accumulation of BPA over time. Gibson et al. (2010) investigated agricultural fields irrigated with wastewater for many years (up to 90 years) at different horizons; concentrations of BPA up to $30.2 \mu \mathrm{g} / \mathrm{kg} \mathrm{d}$.w. were measured, suggesting little evidence of BPA accumulation in soil and no evidence of transport through the different horizons.

Concentrations of BPA in sediments range between $<0.24$ and $492 \mu \mathrm{g} / \mathrm{kg}$ d.w. Values between 66 and $343 \mu \mathrm{g} / \mathrm{kg}$ d.w. were measured by Heemken et al. (2001) in the Elbe River; the highest concentration was observed downstream to a chemical factory. The authors monitored also the changes during 21 months of the BPA concentration in one of the most impacted sampling point, observing concentrations ranging between 127 and $322 \mu \mathrm{g} / \mathrm{kg}$ d.w. In Kawahata et al. (2004), the highest values were observed in areas affected by high pollution and/or downstream of commercial and industrial sites. Fu et al. (2007) studied the distribution of BPA in sediments collected in the Jiaozhou Bay (China) and at five monitoring stations located in the surrounding rivers; BPA was detected in all samples from the bay at concentrations between 0.7 and $20.3 \mu \mathrm{g} / \mathrm{kg} \mathrm{d.w}$. and at concentrations between 2.4 and $27.3 \mu \mathrm{g} / \mathrm{kg}$ d.w. in samples from the river sediments, resulting in similar ranges of concentrations. Pojana et al. (2007) investigated the occurrence of BPA in sediment samples collected at four stations in the Venice Lagoon close to municipal wastewater and industrial discharges; BPA was detected in seven out of eight samples at values up to $118 \mu \mathrm{g} / \mathrm{kg}$ d.w. in the sampling station nearest to the plant discharge.

\section{BPA in groundwater and surface water}

Reported concentrations of BPA in groundwater vary between 0.001 and $20 \mathrm{mg} / \mathrm{m}^{3}$. Lacorte et al. (2002) analyzed groundwater collected at an agriculture area of Catalonia (Spain) treated with a pesticide containing traces of BPA $\left(1.5 \mathrm{mg} / \mathrm{m}^{3}\right.$ in the pesticide), resulting in concentrations between $<0.01$ and $0.35 \mathrm{mg} / \mathrm{m}^{3}$. Latorre et al. (2003) performed measurements in groundwater collected from agriculture sites in northern Spain; the highest level $\left(>1.5 \mathrm{mg} / \mathrm{m}^{3}\right)$ was found next to grape cultivations. Godejohann et al. (2009) performed systematic analyses of groundwater near a former ammunition destruction site in Switzerland; BPA concentrations were about $12-13 \mathrm{mg} / \mathrm{m}^{3}$. In USEPA (2010a), the average concentrations of BPA in groundwater in the USA vary between 0.0041 and $1.9 \mathrm{mg} / \mathrm{m}^{3}$, with a range of values of 0.006 $2.55 \mathrm{mg} / \mathrm{m}^{3}$. Stuart et al. (2011) reported about a survey on micropollutants in groundwater in England, with BPA concentrations up to $20 \mathrm{mg} / \mathrm{m}^{3}$; the distribution of detections was clearly split into two areas, southern England and Midlands. 
BPA in surface water is reported between $<0.001$ and $92 \mathrm{mg} / \mathrm{m}^{3}$. Azevedo et al. (2001) detected BPA in $51 \%$ of the analyzed samples of river and coastal waters from Portugal; authors observed values greater than $2 \mathrm{mg} / \mathrm{m}^{3}$ only in two sampling points located near industrial areas. Heemken et al. (2001) measured the concentration of BPA in the Elbe River and in some of its tributaries between 0.017 and $0.776 \mathrm{mg} / \mathrm{m}^{3}$; BPA probably originated from an industrial plant manufacturing epoxy resins at the German-Czech border and from a municipal sewage plant. Basheer et al. (2004) collected surface seawater samples at different locations along the Singapore coastline, encompassing both inshore and offshore sampling locations; BPA concentrations were between $<0.002$ and $2.47 \mathrm{mg} / \mathrm{m}^{3}$. In general, BPA concentration in samples obtained from offshore locations were lower than inshore samples. Kawahata et al. (2004) measured appreciable concentrations of BPA in water samples (between 0.036 and $0.08 \mathrm{mg} / \mathrm{m}^{3}$ ) in the most populated areas; values below detection limits $\left(0.005 \mathrm{mg} / \mathrm{m}^{3}\right)$ were measured at other locations. Vethaak et al. (2005) measured low concentrations of BPA $\left(<0.009-1 \mathrm{mg} / \mathrm{m}^{3}\right)$ in half of Dutch rainwater and surface water samples; the majority of samples had nanograms per liter, with few higher exceptions. Patrolecco et al. (2006) investigated the presence of BPA in water along the Tiber River (Italy); BPA concentrations were rather constant along the studied tract both in summer $\left(0.06-0.09 \mathrm{mg} / \mathrm{m}^{3}\right)$ and in winter $\left(<0.03-0.14 \mathrm{mg} / \mathrm{m}^{3}\right)$. Loos et al. (2007) monitored river waters in two textile industry regions, in Belgium (south Ghent) and in Italy (south Como). Similar values were obtained in both cases, with Belgian concentrations between $<0.002$ and $0.055 \mathrm{mg} / \mathrm{m}^{3}$ and Italian data between $<0.002$ and $0.175 \mathrm{mg} / \mathrm{m}^{3}$. Fu et al. (2007) measured BPA concentrations between 0.0015 and $0.0925 \mathrm{mg} / \mathrm{m}^{3}$ in water samples in the Jiaozhou Bay; higher values (an order of magnitude) were found in rivers surrounding the bay $\left(0.0168-0.262 \mathrm{mg} / \mathrm{m}^{3}\right)$. Pojana et al. (2007) measured BPA in water samples in the Venice Lagoon, with values between $<0.001$ and $0.145 \mathrm{mg} /$ $\mathrm{m}^{3}$; the highest values were measured at the sampling stations in the proximity of an industrial effluent discharge point and of a municipal and industrial wastewater treatment plant. USEPA (2010a) reported a range of BPA average concentration in surface water of $0.012-0.14 \mathrm{mg} / \mathrm{m}^{3}$ and a range of data of $0.0009-12 \mathrm{mg} / \mathrm{m}^{3}$. Wu et al. (2013) measured concentrations of BPA in waters from Huangpu River and its tributaries (China) in winter and in summer, but the BPA levels in surface waters showed no clear seasonal pattern. Also Xu et al. (2014) did not observe seasonal variation of BPA in the seawaters of a marine reserve in Hong Kong. Gorga et al. (2015) carried out an extensive monitoring campaign on several Spanish rivers observing concentrations of BPA ranging from $<0.00011$ to $0.649 \mathrm{mg} / \mathrm{m}^{3}$; the higher values were found in well-known contaminated sites, near big cities or near industrial areas in the Llobregat and Ebro river basins.

\section{BPA in biota and food}

Many authors studied the migration of BPA and its derivatives from polymer packaging into food, especially under the effect of high temperature (e.g., microwave heating). Polycarbonate hydrolysis is the dominant mechanism responsible for BPA release from the polymer surface to the contacting liquids (Mercea 2009). Concentrations between 0.1 and $790 \mu \mathrm{g} / \mathrm{kg}$ fresh weight (f.w.) were found in food and $<0.00073$ and $0.86 \mathrm{mg} / \mathrm{m}^{3}$ in drinking waters/commercial drinks from different countries. The highest values in canned food were due to epoxy resins used as internal coating. For this reason, since 2001, epoxy resin films have been largely replaced with polyethylene terephthalate films (Huang et al. 2012; WrightWalters et al. 2011). Basheer et al. (2004) measured concentrations of BPA in seafood samples (prawn, crab, blood cockle, white clam, squid, fish) purchased from a local supermarket in Singapore, resulting in significant values in all samples (between 13.3 and $213.1 \mu \mathrm{g} / \mathrm{kg}$ f.w.); the maximum value was found in crab. Sun et al. (2006) investigated canned food samples purchased in Singapore; detectable amounts of BPA were found in all samples, with concentrations between 32.8 and $164.5 \mu \mathrm{g} / \mathrm{kg}$ f.w. Shao et al. (2007) measured BPA in different types of fresh meat purchased in Beijing; BPA was detectable in 13 out of 27 samples, with concentrations between 0.33 and $7.08 \mu \mathrm{g} / \mathrm{kg}$ f.w. High concentrations of BPA were found in aquatic animals (fish and duck meat), due to the contamination of the aquatic environment. Cao et al. (2011) analyzed foods from four different stores in Quebec City (Canada); among the 154 food samples, BPA was detected in 55 samples, with concentrations from 0.20 to $106 \mu \mathrm{g} / \mathrm{kg}$ f.w. BPA levels in raw vegetable samples (not canned) were low, while BPA was detected at high concentrations in all the canned samples. BPA was not detected in any of the bottled water samples. Noonan et al. (2011) examined 78 canned and 2 frozen foods purchased from retail stores in Washington, DC, and in the surrounding Maryland (USA). BPA was detected in 71 out of 78 samples of canned foods, at concentration from $<2$ to $730 \mu \mathrm{g} / \mathrm{kg}$ f.w.; BPA was not detected in the frozen foods. The concentrations in canned fruits were lower than in other canned foods; data were consistent with the general industry practice of using tin and not epoxy phenolic films in canned fruit containers. Gyllenhammar et al. (2012) analyzed the levels of BPA in food from a typical food market basket purchased from two store chains in four major Swedish cities. Concentrations above the limit of quantification $(2 \mu \mathrm{g} /$ $\mathrm{kg}$ f.w.) were found in fish $(2.5-29 \mu \mathrm{g} / \mathrm{kg}$ f.w.), meats (6.9$13 \mu \mathrm{g} / \mathrm{kg}$ f.w.), potatoes $(2.2 \mu \mathrm{g} / \mathrm{kg}$ f.w. $)$, and dairy products (2.4 $\mu \mathrm{g} / \mathrm{kg}$ f.w.). Lu et al. (2013) analyzed BPA in fresh fruits and vegetables commercially available in Florida (USA); concentrations between 0.2 and $4.3 \mu \mathrm{g} / \mathrm{kg}$ f.w. and between 2 and $9 \mu \mathrm{g} / \mathrm{kg}$ f.w., respectively, were found. Dodgen et al. (2013) investigated the accumulation of BPA in different parts 
of lettuce and collards, pointing out the poor translocation of BPA from roots to the upper tissues after uptake: in the stem and leaves, concentration ranges $0.22-0.36$ and $1.42-3.05 \mu \mathrm{g} /$ $\mathrm{kg}$ f.w. were observed for lettuce and collards, respectively, but the values measured in the roots were greater by 3-2 orders of magnitude (441.7 and $199.6 \mu \mathrm{g} / \mathrm{kg}$ f.w.). Maggioni et al. (2013) evaluated concentrations of BPA in drinking waters from public fountains in 35 Italian cities and in bottled mineral waters; the highest concentration of BPA, $0.102 \mathrm{mg} /$ $\mathrm{m}^{3}$, was detected only in one sample in water from public fountains, while in the other samples, the amount was only slightly above the quantification limit $\left(0.00073 \mathrm{mg} / \mathrm{m}^{3}\right)$.

Based on BPA concentrations in food and food consumption, a daily dietary BPA intake of $0.02-0.081 \mu \mathrm{g} / \mathrm{kg} /$ day for adults and $0.22-0.33 \mu \mathrm{g} / \mathrm{kg} /$ day for infants was estimated (Basheer et al. 2004; Sun et al. 2006; Shao et al. 2007; Cao et al. 2011; Gyllenhammar et al. 2012; Noonan et al. 2011; Lu et al. 2013). At present, the dietary intake of BPA appears to be the primary source for human exposure.

\section{Nonylphenol (NP)}

$\mathrm{NP}$ is a term used to refer to a wide group of isomeric compounds $\left(\mathrm{C}_{15} \mathrm{H}_{24} \mathrm{O}\right)$ consisting of a nine-carbon alkyl chain bond to a phenol ring (Table 1). The various isomers can differ either in the degree of alkyl chain branching or in the position on the phenol ring. The NP isomers most produced and measured in the environment is 4-NP. NP is used as a formulant in pesticides, as a lubricating oil additive, as a catalyst in epoxy resins curing, at industrial laundries and, in the past, to produce nonylphenol ethoxylates (NPEs) for consumer products (e.g., surfactants, detergents, wetting agents, dispersants, defoamers, de-inkers, antistatic agents) (CCME 2002; European Parliament 2003; USEPA 2010b). As tris(4NP)phosphite, it is an antioxidant for the stabilization of rubber, vinyl polymers, polyolefins, and styrenics. In 2010, the US demand for NP was 380 million pounds (ICIS 2007 in USEPA 2010b).

\section{Toxicity}

NP is an estrogen agonist (ECHA 2014). It is highly irritating and corrosive to skin and eyes, but it does not have significant skin-sensitizing potential. The acute (oral and dermal) toxicity is low. NP carcinogenicity data give some reason for concern, though more data are needed (ICIS 2007). NP is highly toxic to fish, aquatic invertebrates, and aquatic plants (OEHHA 2009).

Bakke (2003) proposed a RfD value of $0.10 \mathrm{mg} / \mathrm{kg} / \mathrm{day}$, which should be protective for human health under chronic exposure to NP and NPEs, and the Danish Institute of Safety and Toxicology (DIST) derived a preliminary tolerable daily intake (TDI) value for NP of $5 \mu \mathrm{g} / \mathrm{day} / \mathrm{kg}$ body weight (Danish EPA 2000).

\section{Environmental fate and transport}

NP is a viscous liquid at room temperature (Kawahata et al. 2004; USEPA 2010b) and is primarily released into the environment through the discharge of municipal and industrial wastewater into surface waters (Writer et al. 2012). Pathways to the terrestrial environment include the spraying of pesticides containing NP or NPEs as formulates, landfilling of sludge, or the application of sewage sludge or pulp and paper mill sludge to agricultural soils (Soares et al. 2008; Brown et al. 2009). However, Brown et al. (2009) suggested that in practical field situations, where typical biosolids (NP $<1000 \mathrm{mg} / \mathrm{kg})$ are used at agronomic rates $\left(<2.0 \mathrm{~kg} / \mathrm{m}^{2}\right), \mathrm{NP}$ does not accumulate and plant uptake or water quality impairment is minimal.

NP can also be the products of biodegradation of alkylphenol polyethoxylates. These compounds, in fact, biodegrade by stepwise loss of ethoxy groups, resulting in the formation at the end of various hydrophobic alkylphenols (Ying and Kookana 2003). Thus, NP and NPEs are constituents of untreated and insufficiently treated wastewater and are also metabolites of widely used alkylphenolic compounds. It has been shown that the formation of NP is favored under anaerobic conditions, but it was also reported under aerobic conditions (Micic and Hofmann 2009). The formation of NP from its precursors has been observed in anaerobic sludge treatment (Ahel et al. 1994), surface reservoir sediments (Micić et al. 2013), and estuarine sediments (Lee Ferguson et al. 2003)

Due to its physical-chemical properties (Table 2), such as low water solubility and high $\log \left(K_{\mathrm{OC}}\right)$ values, sorption plays an important role on NP fate and transport in soil-water systems and river sediments (Bennie et al. 1997; Sekela et al. 1999; Azevedo et al. 2001; Bester et al. 2001; Heemken et al. 2001; Fries and Puttmann 2003; Jonkers et al. 2003; Rice et al. 2003; Basheer et al. 2004; Kawahata et al. 2004; Vitali et al. 2004; Cespedes et al. 2005; Vethaak et al. 2005; Patrolecco et al. 2006; Fu et al. 2007; Loos et al. 2007; Pojana et al. 2007; Wu et al. 2007; Micic and Hofmann 2009; Chen et al. 2013), where it is moderately persistent (OEHHA 2009; Li et al. 2013a). Liao et al. (2014) and Roberts et al. (2014) reported that the amount of soil organic matter dominated the sorption capacity of 4-NP and NP to different soils though a clear linear relationship was not evident. Sorption process reached equilibrium in $6 \mathrm{~h}$, with a first rapid sorption stage (30 min ahead) followed by a slow sorption stage (30 min afterward).

Similar results were also reported for sorption in aquatic sediments in Ding et al. (2014), even slowing down of the 
process was observed in the presence of biofilm. Shchegolikhina et al. (2012), accordingly, observed also NP extractability from soil, with water and other agents, decreasing at increasing contact time with soil. In marine sediments, NP sorption is enhanced under high salinity (Yang et al. 2011).

NP is not likely to volatilize from soil and is rapidly degraded by hydroxyl radicals in the atmosphere (USEPA 2010b). NP is moderately bioaccumulative (OEHHA 2009).

NP undergoes photolysis in water. In Martínez-Zapata et al. (2013), it was degraded in ultrapure water due to direct photolysis under solar irradiation (300-800 nm) according to a first-order kinetic. Fe(III) and humic acids had a significant synergistic effect. Li et al. (2013b) investigated NP photolysis by sunlight. In pure water, the pseudo-first-order rate constant decreased from $6.73 \times 10^{-3}$ to $1.57 \times 10^{-3} \mathrm{l} / \mathrm{min}$ as the NP initial concentration increased from $40 \mathrm{mg} / \mathrm{m}^{3}$ to $5.0 \mathrm{~g} / \mathrm{m}^{3}$; in seawater, the removal rate was slightly slower, the difference being ascribed to the presence of competing species. Similar results were observed by Neamtu and Frimmel (2006).

NP undergoes aerobic biodegradation in water, sediment, and soil systems, but high concentrations can be toxic to microorganisms (EC 2002). Mineralization has been observed in a variety of soil types, including agricultural soils of various textures, noncultivated temperate soils, and soils from the Canadian tundra (Topp and Starratt 2000 in CCME 2002). Gabriel et al. (2008) investigated the degradation of technical NP (a mixture of more than 100 isomers) by Sphingobium xenophagum Bayram; the strain degraded NP isomers differentially, being those with less bulkiness at the $\alpha$-carbon and with four to six carbon atoms mainly alkyl chain being degraded more efficiently. Lu and Gan (2014) compared biodegradation kinetics of a large suite of NP isomers in river sediments under both oxic or anoxic conditions, reporting half-lives of NP isomers sediment ranging from 0.9 to 13.2 days under oxic conditions and from 15.1 to 20.1 days under slightly reduced conditions. Under reduced conditions, the persistence of NP isomers generally increased with estimated first-order half-lives of NP isomers greater than 200 days, with negligible dissipation under strongly reduced conditions.

Chang et al. (2004) observed anaerobic degradation of NP in a sediment-water system by sulfate-reducing bacteria, methanogens, and eubacteria. Fungi can degrade NP exclusively under aerobic conditions (Corvini et al. 2006a). Rozalska et al. 2010 tested filamentous fungi Gliocephalotrichum simplex to degrade 4-n-NP $\left(50 \mathrm{~g} / \mathrm{m}^{3}\right)$, which was removed by $88 \%$ after $24 \mathrm{~h}$ of incubation and almost completely after $48 \mathrm{~h}$. In the same study, 4-n-NP at $100 \mathrm{~g} / \mathrm{m}^{3}$ was also removed, but at a slower rate.

\section{Degradation byproducts}

Li et al. (2013b) observed the formation of 4-nonyl-catechol after natural irradiation of NP in water. The authors also detected n-nonoic acid in irradiated pure water, but not in seawater.

Corvini et al. (2006b) studied the degradation pathways of NP by Sphingomonas sp. TTNP3, a microbial strain that exhibited high degradation capabilities toward NP used as sole carbon and energy source. The major metabolite in the degradation pathway was hydroquinone, which was further degraded to organic acids (succinate and 3,4-dihydroxy butanedioic acid); benzenediol and alkyloxy derivatives were the dead-end products. Rozalska et al. (2010) investigated the metabolic degradation pathway of 4-n-NP by the nonligninolytic filamentous fungi $G$. simplex, resulting in two possible routes. In one route, carbon detachment brought to 4-hydroxyphenylheptanoic acid and then to 3-(4hydroxyphenyl)propanoic acid, which was transformed into 4-(1-hydroxyvinyl)phenol, on a side route, and to 2-(4hydroxyphenyl)acetic acid and 4-hydroxybenzoic acid, on the main route. In the second route, hydroxylation at the ninth position (close to the aromatic ring) and carboxylation at the first position (distal carbon) of the nonyl-moiety brought to 9hydroxy-9-(4-hydroxyphenyl)nonanoic acid. In $6 \mathrm{~h}$ of incubation, 4-hydroxybenzoic acid was the major metabolite. After $72 \mathrm{~h}$ of incubation, no toxic effects were observed.

\section{Environmental evidence}

Table 4 summarizes the major studies on NP concentrations in different environmental matrices and food.

\section{NP in soil and sediments}

Few studies are available in the literature on NP occurrence in soil. All the authors focused on agricultural soils to highlight the effects of sludge amendment and irrigation with untreated wastewater.Vikelsøe et al. (2002) studied the distribution of NP in dressed and fertilized agricultural soils in Denmark. NP concentrations between 0.01 and $0.98 \mu \mathrm{g} / \mathrm{kg}$ d.w. were found in unamended soils, soils fertilized with manure, or with limited amounts of sewage sludge and $34 \mu \mathrm{g} / \mathrm{kg}$ at runoff points. Higher concentrations of NP $(1.45-2.43 \mathrm{mg} / \mathrm{kg})$, persisting up to 8 years after amendment had ceased, were instead measured in soils exposed to a high addition of sewage sludge. Similar NP values were also reported for sludgeamended site in Canada (CCME 2002). In Mexican agriculture fields irrigated with untreated wastewater for 10 to 90 years, Gibson et al. (2010) measured NP ranging between $<25$ and $299 \mu \mathrm{g} / \mathrm{kg}$ d.w., indicating only little evidence of NP accumulation in soils and poor evidence of migration through the different horizons in soil.

Analytical data of sediment samples point out a variability up to 4 orders of magnitude: the reported concentrations of NP range from $3.6 \mu \mathrm{g} / \mathrm{kg}$ d.w. to $72 \mathrm{mg} / \mathrm{kg}$ d.w., with the highest values registered in lakes (Bennett and Metcalfe 1997; Wu 
Table 4 NP concentrations in various environmental matrices and in food (percentages between brackets represent the detection frequency)

\begin{tabular}{|c|c|c|c|}
\hline Reference & Location & Units & Value \\
\hline \multicolumn{4}{|l|}{ Soils } \\
\hline CCME (2002) & Soil amended with sludge, Canada & $\mu \mathrm{g} / \mathrm{kg}$ d.w. & 2720 \\
\hline \multirow[t]{2}{*}{ Vikelsøe et al. (2002) } & $\begin{array}{l}\text { Unamended, manured or artificially fertilized soils } \\
\text { and soils amended with limited amounts of } \\
\text { sewage sludge, Denmark }\end{array}$ & $\mu \mathrm{g} / \mathrm{kg}$ d.w. & $\begin{array}{l}0.01-0.98 \\
\text { Mean } 0.37\end{array}$ \\
\hline & Soil amended with high amounts of sewage sludge, Denmark & $\mu \mathrm{g} / \mathrm{kg}$ d.w. & $\begin{array}{l}1450-2430 \\
\text { Mean } 1940\end{array}$ \\
\hline Gibson et al. (2010) & Agricultural fields irrigated with wastewater, Tula Valley, Mexico & $\mu \mathrm{g} / \mathrm{kg}$ d.w. & $<25-299$ \\
\hline \multicolumn{4}{|l|}{ Sediments } \\
\hline $\begin{array}{l}\text { Bennett and } \\
\text { Metcalfe (1997) }\end{array}$ & Great Lakes, USA and Canada & $\mu \mathrm{g} / \mathrm{kg}$ d.w. & $\begin{array}{l}<46-37,800 \\
\text { Mean } 3000\end{array}$ \\
\hline Bennie et al. (1997) & Great Lakes and St. Lawrence River in 1995, USA and Canada & $\mu \mathrm{g} / \mathrm{kg}$ d.w. & $\begin{array}{l}170-72,000 \\
\text { Mean 10,600 }\end{array}$ \\
\hline Yamashita et al. (2000) & Tokyo Bay, Japan & $\mu \mathrm{g} / \mathrm{kg}$ d.w. & $<10-5540$ \\
\hline \multirow[t]{2}{*}{ Bester et al. (2001) } & Bight in the North Sea, Germany & $\mu g / \mathrm{kg}$ d.w. & $\begin{array}{l}10-153 \\
\text { Mean } 55\end{array}$ \\
\hline & Open sea, North Sea, Germany & $\mu \mathrm{g} / \mathrm{kg}$ d.w. & $\begin{array}{l}<10-55 \\
\text { Mean } 34(40 \%)\end{array}$ \\
\hline Heemken et al. (2001) & Elbe River and some of its tributaries, Germany & $\mu \mathrm{g} / \mathrm{kg}$ d.w. & $\begin{array}{l}367-1378 \\
\text { Mean } 640\end{array}$ \\
\hline Jonkers et al. (2003) & Western Scheldt and Rhine estuaries, Holland & $\mu \mathrm{g} / \mathrm{kg}$ d.w. & $\begin{array}{l}<0.4-1080 \\
\text { Mean } 19.5(94 \%)\end{array}$ \\
\hline Kannan et al. (2003) & Kalamazoo River, USA & $\mu \mathrm{g} / \mathrm{kg}$ d.w. & $<5.5-15.3$ \\
\hline Rice et al. (2003) & Cuyahoga River, Ohio (USA) & $\mu \mathrm{g} / \mathrm{kg}$ d.w. & $\begin{array}{l}75-340 \\
\text { Mean } 180\end{array}$ \\
\hline Kawahata et al. (2004) & $\begin{array}{l}\text { Estuarine and marine sediments from Okinawa, } \\
\text { and Ishigaki Islands, Japan }\end{array}$ & $\mu \mathrm{g} / \mathrm{kg}$ d.w. & $\begin{array}{l}<5-46 \\
\text { Mean } 30.5(47 \%)\end{array}$ \\
\hline Vitali et al. (2004) & Rieti District, Italy & $\mu \mathrm{g} / \mathrm{kg}$ d.w. & $\begin{array}{l}44-567 \\
\text { Mean } 205\end{array}$ \\
\hline Vethaak et al. (2005) & Fresh, marine, and estuarine sediments, The Netherlands & $\mu \mathrm{g} / \mathrm{kg}$ d.w. & $\begin{array}{l}<10-3800 \\
\text { Median } 160(91 \%)\end{array}$ \\
\hline Lara-Martin et al. (2006) & Marine and estuarine sediments from Bay of Cadiz, Spain & $\mu \mathrm{g} / \mathrm{kg}$ d.w. & $\begin{array}{l}13-225 \\
\text { Mean } 108\end{array}$ \\
\hline Patrolecco et al. (2006) & Tiber River, Italy & $\mu \mathrm{g} / \mathrm{kg}$ d.w. & $\begin{array}{l}50-970 \\
\text { Mean } 414\end{array}$ \\
\hline Fu et al. (2007) & $\begin{array}{l}\text { Estuarine and marine sediments from Jiaozhou Bay } \\
\text { and surrounding rivers, China }\end{array}$ & $\mu \mathrm{g} / \mathrm{kg}$ d.w. & $\begin{array}{l}3.6-39,700 \\
\text { Mean } 3670\end{array}$ \\
\hline Pojana et al. (2007) & Sediments in Venice Lagoon, Italy & $\mu \mathrm{g} / \mathrm{kg}$ d.w. & $\begin{array}{l}47-192 \\
\text { Mean } 89\end{array}$ \\
\hline Wu et al. (2007) & Urban lakes in Wuhan City, China & $\mu \mathrm{g} / \mathrm{kg}$ d.w. & $\begin{array}{l}3540-32,430 \\
\text { Mean } 10,490\end{array}$ \\
\hline $\begin{array}{l}\text { Micic and } \\
\text { Hofmann (2009) }\end{array}$ & Danube River, Germany & $\mu \mathrm{g} / \mathrm{kg}$ d.w. & $\begin{array}{l}<20-2830 \\
\text { Mean } 130\end{array}$ \\
\hline Gong et al. (2011) & Major tributaries in Pearl River system, China & $\mu \mathrm{g} / \mathrm{kg}$ d.w. & $\begin{array}{l}31-21,885 \\
\text { Mean } 3686\end{array}$ \\
\hline Klosterhaus et al. (2013) & San Francisco Bay, USA & $\mu \mathrm{g} / \mathrm{kg}$ d.w. & $\begin{array}{l}21.5-86.3 \\
\text { Mean } 34.7\end{array}$ \\
\hline Micić et al. (2013) & Iron Gate I Reservoir on the Danube River, Romania & $\mu \mathrm{g} / \mathrm{kg}$ d.w. & $80-470$ \\
\hline Wu et al. (2013) & Huangpu River and its tributaries, China & $\mu \mathrm{g} / \mathrm{kg}$ d.w. & $10.34-337.73$ \\
\hline \multirow[t]{3}{*}{ Koniecko et al. (2014) } & Surface sediments of the Gulf of Gdansk, Poland - rivers & $\mu \mathrm{g} / \mathrm{kg}$ d.w. & $<0.08-4.93$ \\
\hline & Surface sediments of the Gulf of Gdansk, Poland - coastal stations & $\mu \mathrm{g} / \mathrm{kg}$ d.w. & $<0.08-13.56$ \\
\hline & $\begin{array}{l}\text { Surface sediments of the Gulf of Gdansk, Poland — stations } \\
\text { below } 4 \mathrm{~m} \text { depth }\end{array}$ & $\mu \mathrm{g} / \mathrm{kg}$ d.w. & $<0.08-249.08$ \\
\hline Duan et al. (2014) & Surface sediments of the Yellow Sea and East China Sea, China & $\mu \mathrm{g} / \mathrm{kg}$ d.w. & $349.5-1642.8$ \\
\hline
\end{tabular}


Table 4 (continued)

\begin{tabular}{|c|c|c|c|}
\hline Reference & Location & Units & Value \\
\hline & & & Mean 890.1 \\
\hline Gorga et al. (2014) & Ebro River basin, Spain & $\mu \mathrm{g} / \mathrm{kg}$ d.w. & $\begin{array}{l}36-538 \\
\text { Mean } 177\end{array}$ \\
\hline Stewart et al. (2014) & Estuarine sediments in Auckland, New Zealand & $\mu \mathrm{g} / \mathrm{kg}$ d.w. & $\begin{array}{l}<100-32,000 \\
\text { Median } 153 \\
4-n-N P<100\end{array}$ \\
\hline Gorga et al. (2015) & $\begin{array}{l}\text { Sediments from Ebro, Llobregat, Júcar and } \\
\text { Guadalquivir rivers, Spain }\end{array}$ & $\mu \mathrm{g} / \mathrm{kg}$ d.w. & $<0.24-1693$ \\
\hline \multicolumn{4}{|l|}{ Groundwater } \\
\hline Lacorte et al. (2002) & Agricultural area in Catalonia, Spain & $\mathrm{mg} / \mathrm{m}^{3}$ & $<0.01-0.35$ \\
\hline Latorre et al. (2003) & Agricultural areas in northern Spain & $\mathrm{mg} / \mathrm{m}^{3}$ & $<0.036-0.9(92 \%)$ \\
\hline Félix-Cañedo et al. (2013) & Groundwater in Mexico City, Mexico & $\mathrm{mg} / \mathrm{m}^{3}$ & $<0.001-0.047(43 \%)$ \\
\hline $\begin{array}{l}\text { Loos et al. (2010), } \\
\text { Luo et al. (2014) }\end{array}$ & 23 European countries, Europe & $\mathrm{mg} / \mathrm{m}^{3}$ & $\begin{array}{l}<0.030-3.85 \\
\text { Mean } 0.083(11 \%) \\
\text { 90th percentile } 0.039\end{array}$ \\
\hline \multicolumn{4}{|l|}{ Surface Water } \\
\hline Bennie et al. (1997) & $\begin{array}{l}\text { Great Lakes and St. Lawrence River in } 1995 \text {, } \\
\text { USA and Canada }\end{array}$ & $\mathrm{mg} / \mathrm{m}^{3}$ & $\begin{array}{l}<0.01-0.92 \\
\text { Mean } 0.21(24 \%)\end{array}$ \\
\hline \multirow[t]{2}{*}{ Sekela et al. (1999) } & Upstream of a WWTP, Fraser River, Canada & $\mathrm{mg} / \mathrm{m}^{3}$ & $0.0066-0.0074$ \\
\hline & Downstream of a WWTP, Fraser River, Canada & $\mathrm{mg} / \mathrm{m}^{3}$ & $0.032-0.13$ \\
\hline Azevedo et al. (2001) & River and coastal waters, Portugal & $\mathrm{mg} / \mathrm{m}^{3}$ & $\begin{array}{l}<0.01-30 \\
\text { Mean } 1.2(79 \%)\end{array}$ \\
\hline Bester et al. (2001) & Bight of the North Sea, Germany & $\mathrm{mg} / \mathrm{m}^{3}$ & $0.0007-0.033$ \\
\hline \multirow[t]{2}{*}{ Heemken et al. (2001) } & Elbe River and its tributaries, Germany & $\mathrm{mg} / \mathrm{m}^{3}$ & $\begin{array}{l}0.0008-0.221 \\
\text { Mean } 0.059\end{array}$ \\
\hline & North Sea & $\mathrm{mg} / \mathrm{m}^{3}$ & $\begin{array}{l}0.0003-0.084 \\
\text { Mean }\end{array}$ \\
\hline Fries and Puttmann (2003) & $\begin{array}{l}\text { Rhine, Elbe, Main, Oder, Nidda, and Schwarzbach } \\
\text { rivers, Germany }\end{array}$ & $\mathrm{mg} / \mathrm{m}^{3}$ & $\begin{array}{l}<0.025-1.22 \\
\text { Mean } 0.43\end{array}$ \\
\hline Jonkers et al. (2003) & Western Scheldt and Rhine estuaries, Holland & $\mathrm{mg} / \mathrm{m}^{3}$ & $\begin{array}{l}0.031-0.934 \\
\text { Mean } 0.17\end{array}$ \\
\hline Kannan et al. (2003) & Kalamazoo River, USA & $\mathrm{mg} / \mathrm{m}^{3}$ & $<2.6$ \\
\hline Rice et al. (2003) & Cuyahoga River, Ohio (USA) & $\mathrm{mg} / \mathrm{m}^{3}$ & $\begin{array}{l}0.1-0.5 \\
\text { Mean } 0.24\end{array}$ \\
\hline Basheer et al. (2004) & Surface coastal water, Singapore & $\mathrm{mg} / \mathrm{m}^{3}$ & $\begin{array}{l}0.02-2.76 \\
\text { Mean } 0.95\end{array}$ \\
\hline Kawahata et al. (2004) & $\begin{array}{l}\text { Estuarine and marine waters from Okinawa, } \\
\text { and Ishigaki Islands, Japan }\end{array}$ & $\mathrm{mg} / \mathrm{m}^{3}$ & $\begin{array}{l}<0.05-0.17 \\
\text { Mean } 0.14(29 \%)\end{array}$ \\
\hline Vitali et al. (2004) & Rieti District, Italy & $\mathrm{mg} / \mathrm{m}^{3}$ & $<0.1-1.6$ \\
\hline Cespedes et al. (2005) & Llobregat River basin, Catalonia, Spain & $\mathrm{mg} / \mathrm{m}^{3}$ & $\begin{array}{l}<0.15-37.3 \\
\text { Mean } 5.7(90 \%)\end{array}$ \\
\hline Vethaak et al. (2005) & The Netherlands & $\mathrm{mg} / \mathrm{m}^{3}$ & $\begin{array}{l}<0.11-4.1 \\
\text { Median } 0.99(10 \%)\end{array}$ \\
\hline Patrolecco et al. (2006) & Tiber River, Italy & $\mathrm{mg} / \mathrm{m}^{3}$ & $\begin{array}{l}0.13-0.58 \\
\text { Mean } 0.28\end{array}$ \\
\hline Vousta et al. (2006) & Glatt river, Switzerland & $\mathrm{mg} / \mathrm{m}^{3}$ & $0.068-0.326$ \\
\hline \multirow[t]{2}{*}{ Fu et al. (2007) } & Marine water from the Jiaozhou Bay, China & $\mathrm{mg} / \mathrm{m}^{3}$ & $0.02-0.269$ \\
\hline & Jiaozhou Bay inflowing rivers, China & $\mathrm{mg} / \mathrm{m}^{3}$ & $0.0906-28.6$ \\
\hline Loos et al. (2007) & River water, Belgium & $\mathrm{mg} / \mathrm{m}^{3}$ & $\begin{array}{l}0.32-2.50 \\
\text { Mean } 1.44\end{array}$ \\
\hline Loos et al. (2007) & River water, Italy & $\mathrm{mg} / \mathrm{m}^{3}$ & $\begin{array}{l}0.46-0.70 \\
\text { Mean } 0.56\end{array}$ \\
\hline Pojana et al. (2007) & Venice Lagoon, Italy & $\mathrm{mg} / \mathrm{m}^{3}$ & $<0.0005-0.21$ \\
\hline
\end{tabular}


Table 4 (continued)

\begin{tabular}{|c|c|c|c|}
\hline Reference & Location & Units & Value \\
\hline Wu et al. (2007) & Urban lakes in Wuhan City, China & $\mathrm{mg} / \mathrm{m}^{3}$ & $\begin{array}{l}1.94-32.85 \\
\text { Mean } 11.96\end{array}$ \\
\hline Micic and Hofmann (2009) & Danube River, Germany & $\mathrm{mg} / \mathrm{m}^{3}$ & $<0.1-0.13(18 \%)$ \\
\hline Félix-Cañedo et al. (2013) & Surface water (dams) in Mexico City, Mexico & $\mathrm{mg} / \mathrm{m}^{3}$ & $<0.001-0.655(75 \%)$ \\
\hline Klosterhaus et al. (2013) & San Francisco Bay, USA & $\mathrm{mg} / \mathrm{m}^{3}$ & $<0.00252-0.0729(60 \%)$ \\
\hline \multirow[t]{2}{*}{ Wu et al. (2013) } & Huangpu River and its tributaries, China_-July 2010 & $\mathrm{mg} / \mathrm{m}^{3}$ & $\begin{array}{l}0.0202-0.1075 \\
\text { Mean } 0.074\end{array}$ \\
\hline & Huangpu River and its tributaries, China-November 2010 & $\mathrm{mg} / \mathrm{m}^{3}$ & $\begin{array}{l}0.0926-0.3317 \\
\text { Mean } 0.1606\end{array}$ \\
\hline Esteban et al. (2014) & Manzanares and Jarama rivers, Spain & $\mathrm{mg} / \mathrm{m}^{3}$ & $0.096-1.483$ \\
\hline \multirow[t]{3}{*}{ Luo et al. (2014) } & China & $\mathrm{mg} / \mathrm{m}^{3}$ & $0.036-33.231$ \\
\hline & Greece & $\mathrm{mg} / \mathrm{m}^{3}$ & $0.558-2.704$ \\
\hline & Korea & $\mathrm{mg} / \mathrm{m}^{3}$ & $0.115-0.336$ \\
\hline \multirow[t]{2}{*}{ Xu et al. (2014) } & Seawater Cape D'Aguilar Marine Reserve, Hong Kong—wet season & $\mathrm{mg} / \mathrm{m}^{3}$ & $\begin{array}{l}0.14-0.50 \\
\text { Mean } 0.39\end{array}$ \\
\hline & Seawater Cape D'Aguilar Marine Reserve, Hong Kong_ dry season & $\mathrm{mg} / \mathrm{m}^{3}$ & $\begin{array}{l}0.061-0.33 \\
\text { Mean } 0.11\end{array}$ \\
\hline Zhang et al. (2014) & North Tai Lake Basin, Eastern China & $\mathrm{mg} / \mathrm{m}^{3}$ & $\begin{array}{l}0.089-1.189 \\
\text { Mean } 0.388\end{array}$ \\
\hline Gorga et al. (2015) & $\begin{array}{l}\text { Iber Ebro, Llobregat, Júcar, and Guadalquivir rivers } \\
\text { (Ebro, Llobregat, Júcar, and Guadalquivir) }\end{array}$ & $\mathrm{mg} / \mathrm{m}^{3}$ & $<0.00013-0.391$ \\
\hline \multicolumn{4}{|l|}{ Food and biota } \\
\hline Guenther et al. (2002) & Packed foodstuff from supermarkets, Germany & $\mu \mathrm{g} / \mathrm{kg}$ f.w. & $\begin{array}{l}0.1-19.4 \\
\text { Mean } 6.0\end{array}$ \\
\hline Rice et al. (2003) & Carps from Cuyahoga River, Ohio (USA) & $\mu \mathrm{g} / \mathrm{kg}$ f.w. & $\begin{array}{l}6.6-110 \\
\text { Mean } 53.4\end{array}$ \\
\hline Basheer et al. (2004) & Seafood from supermarkets, Singapore & $\mu \mathrm{g} / \mathrm{kg}$ f.w. & $\begin{array}{l}46.6-197 \\
\text { Mean } 87.7\end{array}$ \\
\hline Loyo-Rosales et al. (2004) & Spring water bottled in HDPE and PVC from supermarkets, USA & $\mathrm{mg} / \mathrm{m}^{3}$ & $\begin{array}{l}0.015-0.300 \\
\text { Mean } 0.104\end{array}$ \\
\hline Ferrara et al. (2005) & Edible marine species from Adriatic Sea, Italy & $\mu \mathrm{g} / \mathrm{kg}$ f.w. & $\begin{array}{l}2.7-1286 \\
\text { Mean } 413\end{array}$ \\
\hline Vethaak et al. (2005) & Edible freshwater specie (bream), The Netherlands & $\mu \mathrm{g} / \mathrm{kg}$ f.w. & $\begin{array}{l}<10-160 \\
\text { Median } 135(24 \%)\end{array}$ \\
\hline Vethaak et al. (2005) & Edible marine specie (flounder) from North Sea Canal, The Netherlands & $\mu \mathrm{g} / \mathrm{kg}$ f.w. & $\begin{array}{l}<10-10 \\
\text { Median } 10(10 \%)\end{array}$ \\
\hline \multirow[t]{2}{*}{ Isobe et al. (2007) } & $\begin{array}{l}\text { Green mussel from India, Indonesia, Singapore, Malaysia, } \\
\text { Thailand, Cambodia, Vietnam, and the Philippines } \\
\text { during 1994-1999 }\end{array}$ & $\mu \mathrm{g} / \mathrm{kg}$ d.w. & $18-663(79 \%)$ \\
\hline & Tokyo Bay during 1994-1999 & $\mu \mathrm{g} / \mathrm{kg}$ d.w. & $47-1347$ \\
\hline Shao et al. (2007) & Meat/seafood from supermarkets in Beijing, China & $\mu \mathrm{g} / \mathrm{kg}$ f.w. & $\begin{array}{l}<0.05-55.98 \\
\text { Mean } 6.87\end{array}$ \\
\hline Ferrara et al. (2008) & Edible marine species from Tyrrhenian Sea, Italy & $\mu \mathrm{g} / \mathrm{kg}$ f.w. & $\begin{array}{l}5-1220 \\
\text { Mean } 147\end{array}$ \\
\hline Cacho et al. (2012) & Plastic packed vegetables from local supermarkets, Spain & $\mu \mathrm{g} / \mathrm{kg}$ f.w. & $<14.5-48(14 \%)$ \\
\hline Diehl et al. (2012) & Marine organisms California estuary, Morro Bay, USA & $\mu \mathrm{g} / \mathrm{kg}$ f.w. & $122-2380$ \\
\hline Gyllenhammar et al. (2012) & Fruits, cereal products, and vegetables commercially available, Sweden & $\mu \mathrm{g} / \mathrm{kg}$ f.w. & $<10-71$ \\
\hline Dodgen et al. (2013) & Lettuce and collards, steam and leaves & $\mu \mathrm{g} / \mathrm{kg}$ f.w. & $1.18-6.95$ \\
\hline Dodgen et al. (2013) & Lettuce and collards, roots & $\mu \mathrm{g} / \mathrm{kg}$ f.w. & $339.2-926.9$ \\
\hline Li et al. (2013c) & Soft commercial drinks & $\mathrm{mg} / \mathrm{m}^{3}$ & $<0.03-0.22(25 \%)$ \\
\hline Lu et al. (2013) & Vegetables and fruits, from local commercial sources, Florida (USA) & $\mu \mathrm{g} / \mathrm{kg}$ f.w. & $\begin{array}{l}<0.3-11.0 \\
4-\mathrm{n}-\mathrm{NP}<0.1-18.5\end{array}$ \\
\hline Maggioni et al. 2013 & PET - bottled water & $\mathrm{mg} / \mathrm{m}^{3}$ & $<0.0077$ \\
\hline
\end{tabular}


Table 4 (continued)

\begin{tabular}{|c|c|c|c|}
\hline Reference & Location & Units & Value \\
\hline Maggioni et al. (2013) & Drinking water from public drinking fountains, Italy & $\mathrm{mg} / \mathrm{m}^{3}$ & $<0.0077-0.084(23 \%)$ \\
\hline Dodder et al. (2014) & Mussels along the California coast, USA & $\mu \mathrm{g} / \mathrm{kg}$ d.w. & $\begin{array}{l}96-3000 \\
\text { Mean } 470 \\
\text { Median } 200\end{array}$ \\
\hline
\end{tabular}

et al. 2007). In sediments, high NP concentrations were generally associated to specific point sources such as industrial plants, or large amount of domestic wastewater entering the river as it flows through urban areas, especially in most populous regions (Fu et al. 2007; Wu et al. 2007; Duan et al. 2014; Stewart et al. 2014). Typically increasing from upstream to downstream was also reported, with higher values often registered in estuarine and coastal sediments (Fu et al. 2007; Gong et al. 2011; Gorga et al. 2015). The presence of NP in freshwater sediments was primarily ascribed to domestic and industrial wastes and to a lesser extent by agricultural activities (pesticide applications, sludge amendment, and irrigation with wastewater). Koniecko et al. (2014) recognized the rivers and surface runoff as the main sources of NP in coastal sediments of the Gulf of Gdansk; however, they also indicated the possibility of atmospheric transportation of black carbon originating from combustion processes on land along with adsorbed alkylphenols. In Central Europe, Micic and Hofmann (2009) detected concentrations of NP between $<0.02$ and $2.83 \mathrm{mg} / \mathrm{kg}$ d.w. in sediment samples collected along the Danube River; important point sources were industrial sites, especially oil refineries, and drains of untreated wastewater. Similar ranges were also measured along the Elbe River and some of its tributaries in Germany (Heemken et al. 2001) and for Rhine and the Western Scheldt estuaries in heavily industrialized areas or in areas receiving both treated and untreated domestic wastewater in the Netherlands (Jonkers et al. 2003). In Italy, concentrations of NP were measured in areas with different soil uses (urban, industrial, agricultural, open country) in the Rieti District, along the Tiber River and in the Venice Lagoon with similar values, ranging between 44 and $970 \mu \mathrm{g} / \mathrm{kg}$ d.w. (Vitali et al. 2004; Patrolecco et al. 2006; Pojana et al. 2007).

In marine sediments, a decrease in NP concentrations with respect to the levels measured in estuarine sediments and also with increasing distances from the coast was often observed (Bester et al. 2001; Vethaak et al. 2005). As an example, Fu et al. (2007) reported NP concentrations between 3.6 and $299 \mu \mathrm{g} / \mathrm{kg}$ d.w. in the sediments of Jiaozhou Bay (China) and between 23.8 and $39700 \mu \mathrm{g} / \mathrm{kg} \mathrm{d.w.} \mathrm{in} \mathrm{sediments} \mathrm{of} \mathrm{inflowing} \mathrm{rivers.}$

In open-sea sediments, some offshore oil/gas drilling platforms were identified as a likely source of NPEs and NP, even if it is not clear if these are due to drilling and production activities or discharges from ships (e.g., cleaning activities) in the areas (Vethaak et al. 2005). Similar to non- and slightly polar organics, a positive correlation of NP with organic carbon content of the sediments was reported, confirming a role of organic carbon for sorption (Jonkers et al. 2003; Gorga et al. 2015). For NP concentrations in sediment, a clear seasonal pattern was not reported as samples may be deposited during a long time.

\section{NP in groundwater and surface water}

NP was measured in groundwater by Lacorte et al. (2002) and Latorre et al. (2003) in two agricultural areas of Spain, with values between below 0.01 (detection limit) and $0.9 \mathrm{mg} / \mathrm{m}^{3}$. More recent monitoring of groundwater resulted in measured NP concentration ranging between the limit of detection, $0.001 \mathrm{mg} / \mathrm{m}^{3}$, and $3.85 \mathrm{mg} / \mathrm{m}^{3}$ (Loos et al. 2010; FélixCañedo et al. 2013; Luo et al. 2014). NP contamination of groundwater was mainly associated to landfill leachate, water from agricultural land, or seepage of septic tanks and sewer systems (Luo et al. 2014).

The measured concentrations of NP in surface waters span between $3 \times 10^{-4}$ and $37.3 \mathrm{mg} / \mathrm{m}^{3}$. Considering NP is highly hydrophobic and liable to adsorb to suspended solids and eventually to accumulate in sediments, authors comparing concentrations of sediments and surface water samples from the same location often observed higher concentration in surface sediments than in surface water (Wu et al. 2007, 2013; Micić et al. 2013). Vitali et al. (2004) also pointed out that recorded dissolved NP high levels were limited to a short distance (a few kilometers) downstream from the source of contamination, as due to chemical-physical characteristics and their adsorption on particulate matter, sediments represent the final sink for NP. As a consequence, high NP in sediments and low concentrations in water was often ascribed to past emissions (Jonkers et al. 2003).

Nevertheless, the spatial distribution of NP in surface water was quite the same of the NP concentrations in sediments, with the highest levels closely related to the input of industrial or domestic wastewater discharges or wastewater treatment plant effluents (Bennie et al. 1997; Sekela et al. 1999; Kannan et al. 2003; Cespedes et al. 2005) and a general increase from 
the upper rural portions of the river to the urbanized and industrialized segments (Esteban et al. 2014; Luo et al. 2014). Azevedo et al. (2001) in Portugal registered especially high (up to $30 \mathrm{mg} / \mathrm{m}^{3}$ ) NP concentrations in industrial districts where tannery and textile industries are located. Loos et al. (2007), in Belgium (south Ghent) and in Italy (south Como), analyzed wastewater treatment plant (WWTP) effluents of textile industries and the receiving rivers and found NP concentrations in the receiving waters upstream the effluent discharge $\left(0.32-2.50 \mathrm{mg} / \mathrm{m}^{3}\right)$ comparable to NP levels in WWTP effluents $\left(0.37-0.73 \mathrm{mg} / \mathrm{m}^{3}\right)$. Despite agriculture is recognized as a minor source of NP in freshwater, Patrolecco et al. (2006) measured NP above $0.30 \mathrm{mg} / \mathrm{m}^{3}$ in water samples collected from the Tiber River (Italy) at heavily exploited rural areas.

In freshwaters in Central Europe, NP up to about $1.3 \mathrm{mg} /$ $\mathrm{m}^{3}$ has been reported (Jonkers et al. 2003; Fries and Puttmann 2003; Micic and Hofmann 2009; Vethaak et al. 2005). By comparing the results of past water monitoring with more recent data, it was also highlighted a decrease in dissolved NP concentrations in European rivers in the last two decades, probably as consequence of the various voluntary restrictions or legislation on the use of NP in household cleaning products and industrial applications together with possible relocation of industrial activities (Fries and Puttmann 2003; Vousta et al. 2006; Micic and Hofmann 2009; Gorga et al. 2014).

In coastal areas, a significant decreasing trend in NP concentrations with the distance from the coast is often reported (Basheer et al. 2004; Heemken et al. 2001; Fu et al. 2007). Significant levels of NP have been occasionally reported in offshore sampling points in the vicinity of industrial areas, jetties, shipyards, marinas and recreational beaches, as well as in shipping lanes, anchorages, and near petroleum refineries (Basheer et al. 2004).

Fu et al. (2007) and Xu et al. (2008) reported of a seasonal trend of dissolved NP concentrations with higher values in summer than in winter. Such finding was ascribed firstly to high temperatures and associated microbial activity, leading to an enhanced degradation of NPEs in marine sediments and hence an increased NP concentrations in water column during summer. In the Hong Kong area, as the summer is also the wet season, it was also assumed a possible effect on NP level in water due to increased surface runoff during rain events (Xu et al. 2008). Kueh and Lam (2008) in Hong Kong measured in storm water NP concentrations between 0.08 and $12 \mathrm{mg} / \mathrm{m}^{3}$.

\section{NP in biota, food, and bottle water}

Significant NP concentrations were found in different foods, with values between 0.1 and $100 \mu \mathrm{g} / \mathrm{kg}$ f.w. and $<7.7 \mu \mathrm{g} / \mathrm{m}^{3}$ and $0.30 \mathrm{mg} / \mathrm{m}^{3}$ in drinking waters $/$ commercial drinks from different countries. In Guenther et al. (2002), NP concentrations in packed foodstuff purchased from supermarkets in Germany spanned between 0.1 and $19.4 \mu \mathrm{g} / \mathrm{kg}$ f.w. The concentration was not related to the food fat content and NP migration into food occurred at different stages of the food production.

High NP concentrations in seafood and various edible marine species were observed in Asia (Basheer et al. 2004; Isobe et al. 2007; Shao et al. 2007), Europe (Ferrara et al. 2005, 2008), and North America (Dodder et al. 2014) at comparable levels, considering the differences in species examined in each study, number of collected samples, period, analytical methods and reporting units, and also different periods.

Measured values of NP in different commercially available vegetables and fruits in Sweden (Gyllenhammar et al. 2012), Spain (Cacho et al. 2012), and Florida (Lu et al. 2013) varied roughly between 5 and $50 \mu \mathrm{g} / \mathrm{kg}$ f.w.

Different accumulation of NP in each species was observed. Significant values were found in carrots and pumpkins (10.4 and $11.3 \mu \mathrm{g} / \mathrm{kg}$ f.w., respectively) and in apples and citruses (17.1 and $29.5 \mu \mathrm{g} / \mathrm{kg}$ f.w., respectively), whereas NP was not detected in strawberries, lettuce, potato, and tomatoes. Dodgen et al. (2013) investigated the accumulation of NP in different parts of lettuce and collards, pointing out the poor translocation of NP from the roots to the upper tissues after uptake: in the stem and leaves, concentration ranges 1.184.31 and $3.79-6.95 \mu \mathrm{g} / \mathrm{kg}$ f.w. were observed for lettuce and collards, respectively, but the values measured in the roots were greater by 3 orders of magnitude ( 926.9 and $339.2 \mu \mathrm{g} / \mathrm{kg}$ f.w. for lettuce and collards, respectively).

Loyo-Rosales et al. (2004) investigated the presence of NP in commercial water bottled in different materials (high-density polyethylene (HDPE), polyethylene terephthalate (PET), polyvinyl chloride (PVC)). NP was found in water contained in HDPE and PVC bottles at values of 29-180 and 15-300 $\mu \mathrm{g} /$ $\mathrm{m}^{3}$, respectively. Maggioni et al. (2013) evaluated concentrations of NP in drinking waters from public fountains in 35 Italian cities and in bottled mineral waters; in all samples, the amount varied from below the quantification limit $\left(7.7 \mu \mathrm{g} / \mathrm{m}^{3}\right)$ up to a maximum of $84 \mu \mathrm{g} / \mathrm{m}^{3}$. These values are similar to the reported NP range in commercial soft drinks (Li et al. 2013c).

Based on the concentrations measured in food and the expected consumption rates, the average daily intake of NP varies between 0.067 and $0.370 \mu \mathrm{g} / \mathrm{kg} /$ day for adults $(60 \mathrm{~kg}$ body weight) (Guenther et al. 2002; Ferrara et al. 2005, 2008; Shao et al. 2007; Gyllenhammar et al. 2012; Lu et al. 2013). Loyo-Rosales et al. (2004) calculated an average NP daily intake from drinking bottled water of $0.36-0.60 \mu \mathrm{g} /$ day. Diet seems the major exposure route for humans.

\section{Benzophenones (BPs)}

Benzophenone (diphenyl ketone, $\left.\mathrm{BP},\left(\mathrm{C}_{6} \mathrm{H}_{5}\right)_{2} \mathrm{CO}\right)$ is composed of two aromatic rings and a carbonyl group (Table 1) 
(NTP 2006). Based on this parental structure, a group of different compounds can be generated through substitutions of hydrogen atoms in the aromatic rings. The physicalchemical properties and the environmental behavior of these derived compounds are not significantly different from those of the parent compound, except for benzophenone-3 (2-hydroxy-4-methoxybenzophenone, BP-3, Table 1), which is also the most commercialized compound of the group (León et al. 2010; Gago-Ferrero et al. 2012; Liu et al. 2012a; Zhang et al. 2013b).

BPs are used as a flavor ingredient, a fragrance enhancer, a perfume fixative, and an additive for plastics, coatings, and adhesive formulations. They are also used in laundry and household cleaning products and in the manufacture of insecticides, agricultural chemicals, hypnotic drugs, antihistamines, and other pharmaceuticals. BPs are used as an ultraviolet (UV)-curing agent in sunglasses and to prevent UV light from damaging scents and colors in products such as perfumes and soaps. BP-3 is commonly used worldwide as a UV filter in cosmetic formulations, such as sunscreens and skin care products, body lotions, hair sprays, hair dyes, and shampoos (Zhang et al. 2011; Liu et al. 2012a). Moreover, they can be added to plastic packaging as a UV blocker, which allows manufacturers to package their products in clear glass or plastic rather than opaque or dark packaging. BPs are widely used as a photoinitiator for inks and varnishes that are cured with UV light (Ricking et al. 2003; Zhang et al. 2011). In 2003, BP production exceeded $453 \mathrm{t}$ in the USA and 10,000 $\mathrm{t}$ in the European Union (NTP 2006).

\section{Toxicity}

BPs have adverse effects on reproduction and hormonal functions of fish (IARC 2010). They can alter endocrine signaling through multiple effects on receptors. The estrogenic activity of BP-3 and BP-1 (2,4-dihydroxybenzophenone) was determined by the estrogenic recombinant yeast assay, resulting in the half-maximal effective concentrations $\left(\mathrm{EC}_{50}\right)$ of 12.5 and $0.058 \mathrm{~g} / \mathrm{m}^{3}$, respectively, and a lowest observed effect concentrations (LOEC) of 1.6 and $0.015 \mathrm{~g} / \mathrm{m}^{3}$, respectively (Gago-Ferrero et al. 2012). No data are available on BP carcinogenicity to humans, though they are classified as group 2B substances, "possible carcinogenic to humans" (NTP 2006; IARC 2010).

Because of their use as an additive in fragrances, cosmetics, pharmaceuticals, insecticides, and household cleaning products, exposure to BPs through dermal contact may be significant. In León et al. (2010), BP-3 applied on the skin was absorbed and readily biotransformed into BP-1, 2,2'-dihydroxy-4-methoxybenzophenone (BP-8), and 2,3,4trihydroxybenzophenone (THB), whose decrease over time was much slower than the parent compound. Dietary sources of exposure include food and drinking water, where BPs might be present due to the addition as a flavoring or the migration from packaging (IARC 2010). The European Commission Scientific Committee on Food set a RfD for oral exposure of $10 \mu \mathrm{g} / \mathrm{kg} /$ day (EC 2005).

Environmental fate and transport

BPs can enter the environment through solid-waste landfill leachate and wastewater treatment plants effluents (Ricking et al. 2003; Jeon et al. 2006). BP is insoluble in water (Table 2). Because of the high $K_{\mathrm{OC}}$ value, BP sorption on soil and sediment organic matter is significant (USEPA 1984). Volatilization can occur to some extent, but due to low vapor pressure, BP is not expected at significant levels in ambient air (USEPA 1984). BP in water can be photodegraded under sunlight exposure (Hayashi et al. 2006). Fujii and Kituchi (2005) observed BP biodegradation in activated sludge caused by a specific microbial strain. BP is persistent in the environment and susceptible to bioaccumulation (Brooks et al. 2009; IARC 2010). Based on the estimated $K_{\mathrm{OC}}$ value (Table 2), BP3 has slight mobility in soil and sorbs significantly on suspended solids and sediments. Volatilization from soil surface and water is not expected to be an important process, though BP-3 in ambient air can exist in both vapor and particulate phase. The potential for BP-3 bioconcentration in aquatic organisms is moderate to high (TOXNET 2014).

BP-3 absorbs light at 288 and $326 \mathrm{~nm}$ and, therefore, is susceptible to direct photolysis by sunlight. However, Rodil et al. (2009) assessed the photostability of BP-3 under sunlight exposure (290 to $800 \mathrm{~nm}$ ) of water samples spiked at 100 $4000 \mathrm{mg} / \mathrm{m}^{3}$, without any significant decrease of BP-3 concentration over a $72 \mathrm{~h}$ irradiation period. Also, Gago-Ferrero et al. (2012) did not observe photodegradation of BP-3 over a $24 \mathrm{~h}$ irradiation period. Vapor-phase BP-3 is degraded in the atmosphere by reaction with photochemically produced hydroxyl radicals, with an estimated half-life of $1.9 \mathrm{~h}$.

BP-3 can be biodegraded in water and soil systems. Liu et al. (2011a) and Liu et al. (2012a) investigated BP-3 biodegradation under oxic and anoxic conditions in water, resulting in BP-3 complete removal in both kinds of microcosms after 42 days of incubation. Anoxic conditions were more favorable than oxic conditions, with measured half-lives of 4.2 and 10.7 days, respectively. Gago-Ferrero et al. (2012) observed high biodegradation rates for BP-3 by white rot fungi Trametes versicolor, down to nondetectable levels in $8 \mathrm{~h}$ of incubation.

\section{Degradation byproducts}

Hayashi et al. (2006) investigated BP byproducts after exposure of an aqueous solution to UV or sunlight irradiation; tworing hydroxylated derivatives were observed (3hydroxybenzophenone and 4-hydroxybenzophenone, 4HB). 
According to Liu et al. (2011a) and Liu et al. (2012a), after 42 days of incubation in microcosms, biodegradation of BP-3 under $\mathrm{Fe}(\mathrm{III})$-reducing conditions produced 4-cresol and BP1 , while BP-1 was detected under oxic, nitrate-reducing and sulfate-reducing conditions.

BP-1 was identified by Gago-Ferrero et al. (2012) as a metabolite produced during degradation of BP-3 by T. versicolor. BP-1 was then degraded to $4,4^{\prime}-$ dihydroxybenzophenone (4DHB) and 4HB. More investigation is necessary to identify transformation products formed in environmental matrices in order to assess the potential environmental risk for BPs compounds (Jurado et al. 2014).

\section{Environmental evidence}

The major papers in the literature reporting of BPs in environmental matrices and food are summarized in Table 5. Aquatic ecosystems in highly urbanized areas are the most important pathway for BPs to enter in the environmental matrices. Shortcomings in wastewater treatment were reported with a removal efficiency for BP-3 ranging between 5596 \% (Kim and Choi 2014); recently, Ávila et al. (2014) observed a value equal to $93 \%$. Oxygen availability promote CEC degradation via aerobic pathways (example for BPA and BP-3); however, the releases of BP products are high due to human and industry activity (Kasprzyk-Hordern et al. 2008). Recently, for BP-3, the most ubiquitous compound, some authors paid attention to the direct diffusion due to the release of sunscreen products in water (Sánchez-Brunete et al. 2011; Kim and Choi 2014). In fact, maximum levels of contamination were observed in swimming pool or, in summer, during bath in recreational areas. In addition to the mentioned compounds (BP, BP-3, BP-1, 4HB, 4DHB, BP-8, THB), in the matrices, benzophenone-4 (BP-4), 2,2-dihydroxy-4.4dimethoxybenzophenone (BP-6), and benzhydrol (BH) were also found.

\section{BPS in soil and sediments}

Concentrations of BP types in soils range between 0.07 and $16.55 \mu \mathrm{g} / \mathrm{kg}$ d.w. Sánchez-Brunete et al. (2011) investigated the concentration of different BPs in soil samples from two agricultural fields and from one industrial site in Spain. Only BP-1 was found at $5.7 \mu \mathrm{g} / \mathrm{kg}$ in the industrial soil and BP-6 at $0.6 \mu \mathrm{g} / \mathrm{kg}$ in the agricultural soil amended with sewage sludge. In Jeon et al. (2006), the parent compound BP among seven UV filters showed both high concentration (approximately $5 \mu \mathrm{g} / \mathrm{kg}$ ) and frequency in ground soil; BP-3 was detected in 5 soil samples out of 33 , at concentrations between 0.73 and $3.88 \mu \mathrm{g} / \mathrm{kg}$ d.w. Due to the importance of adsorption on solid matrices, more investigations would be required; for soil, only few studies are reported in the literature, so it is difficult illustrate the real presence of BPs.
Concentrations of BPs in sediments vary between 0.1 and $110 \mu \mathrm{g} / \mathrm{kg}$ d.w., containing BP-3 between 0.27 and $4.7 \mu \mathrm{g} / \mathrm{kg}$ d.w. Samples of sediments were collected from aquatic ecosystems highly urbanized and industrialized in Songhua River (China), Saginaw River and Detroit River (USA), Magdalena River (Colombia), and Biobio region (Chile) (Zhang et al. 2011; Barón et al. 2013). Nineteen sampling stations in Chile were located close to some important discharges of chemicals, food processing, and urban discharges and 13 sampling stations in Colombia included natural and urban areas of Barranquilla City that has an important industrial district and a seariver port. Highest levels of BP-3 were detected in Colombia; the contrast with the levels found in Chile is explained with the difference in solar radiation levels. In fact, especially in Caribbean Colombian beaches, high tourism activity and use of personal care products could justify the higher BP-3 concentrations in water compared to the Chilean case (Barón et al. 2013). Kameda et al. (2011) measured BP concentration in sediments collected from rivers (polluted by industrial and domestic wastewaters) and lakes (used as the background sites) in Saitama Prefecture, Japan. Values between 2.7 and $58 \mu \mathrm{g} / \mathrm{kg}$ d.w. were found at the polluted sites and between 3.8 and $105 \mu \mathrm{g} / \mathrm{kg}$ d.w. at the background sites. Dry and wet deposition from atmosphere and the recreational activities were thought to be the source of BP-3 at the background sites. Jeon et al. (2006) measured concentrations of different UV filters in sediment samples collected from lakes and rivers in Korea affected by municipal and recreational wastewaters. The parent compound BP was the most detected and had the highest concentrations (1.52 to $9.73 \mu \mathrm{g} / \mathrm{kg}$ d.w.) among the investigated BPs; BP-3 was not detected in any sediment sample. Sánchez-Brunete et al. (2011) analyzed sediments collected in rivers and along the Mediterranean coast in Spain at bathing or recreational areas. BP-6 was at values between 1.2 and $6.1 \mu \mathrm{g} / \mathrm{kg}$ d.w. The authors that compared concentrations of sediments and surface water samples from the same location noticed that BPs in water often appeared to be below the quantification limit: most of contaminants were accumulated in sediment (Jeon et al. 2006; Kim and Choi 2014). The contamination of sediments may pose an unacceptable risk to aquatic organisms, which tend to bioaccumulate the molecules, and to humans through the ingestion of contaminated fish (Barón et al. 2013).

\section{BPs in groundwater and surface water}

Groundwater can be an important water supply resource; however, only few information, reported in this review, on contamination of BPs are available. Stuart et al. (2011) monitored BP concentration in groundwater in England, resulting in values between 0.03 and $2.8 \mathrm{mg} / \mathrm{m}^{3}$. Jurado et al. (2014) evaluated the presence of BPs in the Barcelona aquifers (water is used for street cleaning and to irrigate city gardens) for the 
Table 5 BP concentrations in various environmental matrices and in food (percentages between brackets represent the detection frequency)

\begin{tabular}{lll}
\hline Reference Compound and location & Units Value
\end{tabular}

Soils

Jeon et al. (2006) BPs, South Korea

Sánchez-Brunete et al. (2011) BPs, industrial, and agricultural areas, Spain

Sediments

Jeon et al. (2006)

Pojana et al. (2007)

Sánchez-Brunete et al. (2011)

Kameda et al. (2011)

Zhang et al. (2011)

Zhang et al. (2011)

Barón et al. (2013)

Barón et al. (2013)

Kim and Choi (2014)

Groundwater

Stuart et al. (2011)

Jurado et al. (2014)

Jurado et al. (2014)

Jurado et al. (2014)

Jurado et al. (2014)
BPs, South Korea

BP, Venice Lagoon, Italy

BPs, river and coastal sediments, Spain

BP, rivers and lakes, Saitama Prefecture, Japan

BP-3, Songhua River, China

BPs, Saginaw and Detroit River, USA

$\mathrm{BP}-3$, river areas, estuary and coastal bays, Biobio region, Chile $\mu \mathrm{g} / \mathrm{kg}$ d.w. BP-3, Magdalena River, Colombia

BP-3, rivers, worldwide

BP, England

BPs, Barcelona urban groundwater

BPs, Mallorca street zone

BPs, Poble Sec zone

BPs, Beson River Delta zone $\mu \mathrm{g} / \mathrm{kg}$ d.w.

$\mu \mathrm{g} / \mathrm{kg}$ d.w.

$\mu \mathrm{g} / \mathrm{m}^{3}$

$\mu \mathrm{g} / \mathrm{m}^{3}$

$\mu \mathrm{g} / \mathrm{m}^{3}$

$\mu \mathrm{g} / \mathrm{m}^{3}$

$\mu g / \mathrm{kg}$ d.w. BP 0.82-16.55, mean 4.55 (97\%) BP-3 0.73-3.88, mean $2.65(15 \%)$ BP- $1<0.5$ BP-6 0.5-4.17, mean $1.67(15 \%)$ BH 0.51-6.95, mean $1.8(39 \%)$ 4HB 1.06-4.91, Mean 3.01 (9\%) THB $<0.5$

$\mu \mathrm{g} / \mathrm{kg}$ d.w. $\quad$ BP- $1<0.1-5.7$ (ind) BP-6 $<0.09-0.6$ (agr) BP-3 $<0.1$

BP-8 $<0.07$ $4 \mathrm{HB}<0.07$

$\mu \mathrm{g} / \mathrm{kg}$ d.w. BP 1.52-9.73, mean 4.73 (93\%)

BP- $3<0.1$

BP- $1<0.1$

BP-6 0.5-2.14, mean $0.95(80 \%)$

BH 0.53 , mean $0.53(7 \%)$

$4 \mathrm{HB} 18.38$, mean $18.38(7 \%)$ THB $<0.1$

$\mu \mathrm{g} / \mathrm{kg}$ d.w. $\quad 14-110$

Mean 39.4

$\mu \mathrm{g} / \mathrm{kg}$ d.w. $\quad$ BP-6 $<0.15-6.1$, mean 1.6

BP- $1<0.21$

BP-3 $<0.28$

BP-8 $<0.14$

$4 \mathrm{HB}<0.23$

$\mu \mathrm{g} / \mathrm{kg}$ d.w. $2.7-105$

Mean 34.7

$\mu \mathrm{g} / \mathrm{kg}$ d.w. BP-3 0.272-0.545, mean 0.380 (100\%)

BP- $1<0.14$

BP- $6<0.22$

$4 \mathrm{HB}<0.22$

$\mu \mathrm{g} / \mathrm{kg}$ d.w. BP-3 0.728-4.66, mean 2.34 (100\%)

BP-1 0.259-0.607, mean $0.454(67 \%)$

BP-6 0.133-0.796, mean 0.424 (67\%)

4HB 0.312-0.951, mean 0.53 (50\%)

$<0.4-2.96$

$<0.4-5.38$

$<0.5-27$

$<10-2780$

BP-1 mean 0.9 (16\%), max 19.4

BP-3 mean $2.3(32 \%)$, max 19.2

BP-4 mean $2.8(19 \%)$, max 36.6 4HB mean $0.2(6 \%)$, max 3.5 4DHB mean $0.13(6 \%)$, max 4.1

BP-1 mean 0.78 (43\%), max 3.2 BP-3 mean 7.9 (71\%), $\max 19.2$ BP-4 mean 1.1 (25\%), max 6.4 4HB mean 0.38 (14\%), max 2.6 4DHB mean 0.58 (14\%), max 4.1 BP-3 mean 0.66 (25\%), max 3.4 BP-4 mean 1.8 (10 \%), $\max 21.3$

$\mu \mathrm{g} / \mathrm{m}^{3} \quad$ BP-1 mean $1.9(17 \%), \max 19.4$ BP-3 mean 0.64 (17\%), max 4.4 
Table 5 (continued)

\begin{tabular}{|c|c|c|c|}
\hline Reference & Compound and location & Units & Value \\
\hline & & & $\begin{array}{l}\text { BP-4 mean } 3.8(25 \%), \max 36.6 \\
\text { 4HB mean } 0.29(8 \%), \max 3.5\end{array}$ \\
\hline \multicolumn{4}{|l|}{ Surface water } \\
\hline Balmer et al. (2005) & BP-3, Swiss Lakes & $\mu \mathrm{g} / \mathrm{m}^{3}$ & $\begin{array}{l}<2-35 \\
\text { Mean } 16.1\end{array}$ \\
\hline Jeon et al. (2006) & BPs, rivers and lakes, South Korea & $\mu \mathrm{g} / \mathrm{m}^{3}$ & $\begin{array}{l}\text { BP }<25 \\
\text { BP-3 }<25 \\
\text { BP-1 } 47(4 \%) \\
\text { BP-6 }<25 \\
\text { BH }<25 \\
4 \text { HB } 85(17 \%) \\
\text { THB }<10\end{array}$ \\
\hline Pojana et al. (2007) & BP, Venice Lagoon, Italy & $\mu \mathrm{g} / \mathrm{m}^{3}$ & $\begin{array}{l}<2.6-136 \\
\text { Mean } 30\end{array}$ \\
\hline Kasprzyk-Hordern et al. (2008) & BPs, river Taff, UK & $\mu \mathrm{g} / \mathrm{m}^{3}$ & $\begin{array}{l}\text { BP- } 1<0.3-17 \\
\text { BP- } 2<0.5-284 \\
\text { BP-3 }<15-44 \\
\text { BP-4 }<3-371\end{array}$ \\
\hline Kasprzyk-Hordern et al. (2008) & BPs, river Ely, UK & $\mu \mathrm{g} / \mathrm{m}^{3}$ & $\begin{array}{l}\text { BP- } 1<0.3-13 \\
\text { BP- } 2<0.5-26 \\
\text { BP-3 }<15 \\
\text { BP-4 }<3-323\end{array}$ \\
\hline Fent et al. 2010 & BP-3, river Glatt, Swiss & $\mu \mathrm{g} / \mathrm{m}^{3}$ & $56-68$ \\
\hline Yoon et al. (2010) & BP, Han River, South Korea & $\mu \mathrm{g} / \mathrm{m}^{3}$ & $\begin{array}{l}<50-59 \\
\text { Mean } 52(33 \%)\end{array}$ \\
\hline Yoon et al. (2010) & $\begin{array}{l}\text { BP, effluent-dominated creeks discharging } \\
\text { into Han River, South Korea }\end{array}$ & $\mu \mathrm{g} / \mathrm{m}^{3}$ & $\begin{array}{l}56-130 \\
\text { Mean } 102\end{array}$ \\
\hline Kameda et al. (2011) & $\begin{array}{l}\text { BP, rivers and lakes, Saitama } \\
\text { Prefecture, Japan }\end{array}$ & $\mu \mathrm{g} / \mathrm{m}^{3}$ & $\begin{array}{l}1-68 \\
\text { Mean } 32.2\end{array}$ \\
\hline Kameda et al. (2011) & $\begin{array}{l}\text { BP-3, rivers and lakes, Saitama } \\
\text { Prefecture, Japan }\end{array}$ & $\mu \mathrm{g} / \mathrm{m}^{3}$ & $\begin{array}{l}2-12 \\
\text { Mean } 7\end{array}$ \\
\hline Rodil et al. (2012) & BP-4, rivers in Galicia, Spain & $\mu \mathrm{g} / \mathrm{m}^{3}$ & $\begin{array}{l}2.5-70 \\
\text { Mean } 25\end{array}$ \\
\hline Grabicova et al. (2013) & $\begin{array}{l}\text { BP-3, recreational areas (ponds, rivers) in } \\
\text { South Bohemia, Czech Republic }\end{array}$ & $\mu \mathrm{g} / \mathrm{m}^{3}$ & $12-550$ \\
\hline Grabicova et al. (2013) & $\begin{array}{l}\text { BP- } 4 \text {, recreational areas (ponds, rivers) } \\
\text { in South Bohemia, Czech Republic }\end{array}$ & $\mu \mathrm{g} / \mathrm{m}^{3}$ & $4.0-390$ \\
\hline Kim and Choi (2014) & BP-3, freshwater, worldwide & $\mu \mathrm{g} / \mathrm{m}^{3}$ & $<0.3-125$ \\
\hline \multicolumn{4}{|l|}{ Food } \\
\hline Balmer et al. (2005) & BP-3, fish from Swiss lakes & $\mu \mathrm{g} / \mathrm{kg}$ f.w. & $\begin{array}{l}0.49-3.3 \\
\text { Mean } 1.17\end{array}$ \\
\hline Gago-Ferrero et al. (2013) & BP-3, Guadalquivir River, Spain & $\mu \mathrm{g} / \mathrm{kg}$ d.w. & $\begin{array}{l}<10-24.3 \\
\text { Median } 20.4\end{array}$ \\
\hline
\end{tabular}

first time; BP-3 was the most detected with frequency of $32 \%$ of the samples (other compounds with frequency less than $16 \%$ ). The area under study had presented different levels in terms of concentrations; hot spot concentrations were $19.4 \mu \mathrm{g} /$ $\mathrm{m}^{3}$ (BP-1), $19.2 \mu \mathrm{g} / \mathrm{m}^{3}$ (BP-3), and $36.6 \mu \mathrm{g} / \mathrm{m}^{3}$ (BP-4). Due to large amounts of WWTP effluents, Besòs River Delta was found to be the most polluted in terms of UV filter compounds. Under different redox conditions, BPs could be removed (Jurado et al. 2014); in fact, concentrations in groundwater were lower than those expected from mixing balance of the recharge sources that contributed in Barcelona aquifers.

Concentrations of BPs in surface waters are reported between 0.3 and $550 \mu \mathrm{g} / \mathrm{m}^{3}$. Wastewater is the most important source (Zenker et al. 2008; Fent et al. 2010; Rodil et al. 2012; Jeon et al. 2006); levels decreased with higher river water flow. Balmer et al. (2005) detected concentrations of BP-3 above the detection limit $\left(2 \mu \mathrm{g} / \mathrm{m}^{3}\right)$ in water samples from four 
Swiss lakes out of five $\left(10-35 \mu \mathrm{g} / \mathrm{m}^{3}\right)$; these lakes were selected because of the near municipal wastewater plants or the recreational activities. Comparable level was detected in river Glatt and lake Greifen catchment in Switzerland (Fent et al. 2010). River Glatt, near the city of Zurich, was heavily impacted by human activities and wastewater effluents of 160 , 000 inhabitants. The relative amount of treated wastewater in the river water was about 10-20\%. Rodil et al. (2012) measured the concentration of many emerging pollutants (including BP-3 and BP-4) in water samples collected in the metropolitan area of La Coruna (Spain). BP-4 was detected in $75 \%$ of the surface water samples at concentrations between 2.5 and $70 \mu \mathrm{g} / \mathrm{m}^{3}$. BP-4 was also detected in several drinking water samples, up to a maximum level of $62 \mu \mathrm{g} / \mathrm{m}^{3}$. BP-3 was not found in samples of surface or drinking water. Yoon et al. (2010) investigated the occurrence of wastewaterderived contaminants including BP in water samples collected along the Han River, near the northwest Seoul metropolitan area. BP was detected in six sampling sites out of ten, at concentration between 50 and $130 \mu \mathrm{g} / \mathrm{m}^{3}$. Kameda et al. (2011) measured the concentrations of BP and BP-3 in water samples at polluted and background sites in the Saitama Prefecture (Japan). Values in the range $2-68 \mu \mathrm{g} / \mathrm{m}^{3}$ and $1-$ $57 \mu \mathrm{g} / \mathrm{m}^{3}$ were found for BP and $4-12 \mu \mathrm{g} / \mathrm{m}^{3}$ and $2-10 \mu \mathrm{g} / \mathrm{m}^{3}$ for BP-3. Direct inputs (due to removal from the skin during recreational activities) may not be negligible (Kim and Choi 2014); Grabicova et al. (2013) investigated the occurrence of BPs in water samples from ponds and rivers near recreational area in the South Bohemia, comparing them with unpolluted background areas. The concentrations of both BP-3 and BP-4 in the recreational areas (12-550 and 4.0-390 $\mu \mathrm{g} / \mathrm{m}^{3}$, respectively) were higher than those in the background areas (14-20 and $3.4-37 \mu \mathrm{g} / \mathrm{m}^{3}$, respectively).

\section{BPs in biota and food}

Few cases are available in the literature on BPs in food or aquatic biota. Balmer et al. (2005) detected BP-3 in fish from three Swiss lakes out of five; in particular, roach fish had values between 0.66 and $3.31 \mu \mathrm{g} / \mathrm{kg}$ f.w. Results on fish samples (common carp and Andalusian barbel) collected along the Guadalquivir River basin (Gago-Ferrero et al. 2013) confirmed the bioaccumulation of BP-3. More investigations are necessary; a limit concentration of $0.6 \mathrm{mg} / \mathrm{kg}$ in food was set for the sum of BP and 4-methylbenzophenone (IARC 2010).

\section{Benzotriazoles (BTs)}

BTs are bicyclic heterocyclic compounds containing three nitrogen atoms and a fused benzene ring. 1H-benzotriazole
(BT, $\mathrm{C}_{6} \mathrm{H}_{5} \mathrm{~N}_{3}$, Table 1) is the reference compound of the group because it is the most used and measured in the environment compartments (DECOS 2000; Hart et al. 2004).

BTs are used as additives in fluids to inhibit corrosion of cooling systems and metal machines and in defrosting liquids (DECOS 2000); in particular, the use for defrosting purpose for aircrafts causes significant release on soils (Cancilla et al. 2003; Jia et al. 2006). Some BTs are present in pesticides and herbicides, like UV stabilizers also used in plastic devices to prevent yellowing and degradation of the products (Bhhatarai and Gramatica 2011; Wolschke et al. 2011; Zhang et al. 2011). The global production is high, about $9000 \mathrm{t} / \mathrm{year}$ in the USA (Liu et al. 2011a).

\section{Toxicity}

Although clear antiestrogenic activity of BTs was demonstrated in vitro, no evidence of antiestrogenic activity was observed in vivo assays (Harris et al. 2007). A subchronic, 21 day reproduction toxicity tests using Daphnia magna resulted in a no observed effect concentration of $3 \mathrm{~g} / \mathrm{m}^{3}$; based on these results, a predicted no effect concentration of $0.06 \mathrm{~g} /$ $\mathrm{m}^{3}$ was calculated (Breedveld et al. 2002). BT was classified as toxic to aquatic organisms and can cause long-term adversary effects in the aquatic environment, but it has low toxicity to humans (La Farré et al. 2008; Breedveld et al. 2002). Limited ecotoxicological data are available, mostly from acute toxicity tests on aquatic species. The $\mathrm{EC}_{50}$ values for fish and bacteria are 130 and $41 \mathrm{~g} / \mathrm{m}^{3}$, respectively (Hem et al. 2003). Based on its molecular weight and partition coefficient, dermal absorption might be expected. Contact dermatitis was observed in metalworkers after skin exposure to BT. Based on acute toxicity data in rats (inhalation $\mathrm{LC}_{50} 2153 \mathrm{mg} / \mathrm{m}^{3}$; oral $\mathrm{LD}_{50} 500-965 \mathrm{mg} / \mathrm{kg}$ ), BT should be classified as harmful for inhalation and oral exposure (DECOS 2000).

No occupational exposure limits/standards for BT have been established or recommended (DECOS 2000). USEPA (2010c) calculated a RfD of $0.03 \mathrm{mg} / \mathrm{kg} /$ day for both dermal contact and inhalation. As for carcinogenicity, based on studies in rats and mice, BT was classified as a suspected carcinogen.

\section{Environmental fate and transport}

The discharge of treated municipal wastewater is the greatest potential source for BTs in the environment; nevertheless, overruns of wastewater sewers and atmospheric deposition can be regarded as other possible input sources (Kiss and Fries 2009).

BT has high water solubility (Table 2) and is less sorbable on organic matter than the other emerging contaminants considered in this review (Giger et al. 2006). No sorption of BTs was observed in sandy soils, while peat and compost exhibited 
a certain affinity with the compounds (Breedveld et al. 2002). BT has a weak hydrophobic nature (Cornell et al. 2000 in Breedveld et al. 2002) and is a weak organic acid with $\mathrm{pKa}$ of 8.6 (Andreozzi et al. 1998 in Breedveld et al. 2002).

BTs are slightly sensitive to light and photodegradable (Andreozzi et al. 1998). In Hem et al. (2003), approximately $65 \%$ abatement of BTs was achieved at a dose of $320 \mathrm{mWs} /$ $\mathrm{cm}^{2}$. Benitez et al. (2013) suggested a first-order kinetic for the photodegradation process in water, dependent on the $\mathrm{pH}$ value.

BTs are generally resistant to biodegradation; therefore, they are highly persistent in the aquatic environment (Hogenboom et al. 2009; Liu et al. 2012b). Many studies reported no evidence of microbial degradation of BT and its derivatives. In Liu et al. (2011a), BT half-lives under different redox conditions were between 114 days (aerobic conditions) and 315 days (sulfate-reducing conditions). Breedveld et al. (2002) observed no degradation during a 5 month test under anaerobic conditions, while BT removal under aerobic conditions was ascribed to evaporation due to aeration rather than biodegradation.

\section{Degradation byproducts}

A UV degradation study of BT in aqueous solutions (Hem et al. 2003) evidenced the formation of aniline (1\%w/w of photodegradation byproducts), phenazine (10-20\% $\mathrm{w} / \mathrm{w}$ ), and other unknown byproducts $(89-79 \% w / w)$. The amount of byproducts increased with the UV dose. Irradiation of BT leads to two different routes of degradation: nitrogen elimination (with the production of aniline) followed by hydroxylation, and dimerization (phenazine was the main byproduct) (Benitez et al. 2013).

In Liu et al. (2012b), the degradation of four BTs in water samples was studied in aerobic and anaerobic microcosms, by using activated and digested sludge from a wastewater treatment plant. Five degradation byproducts were identified under aerobic conditions (phenol, phthalic acid, 1methylbenzotriazole, 4-methoxy,1H-benzotriazole, and 5methoxy,1H-benzotriazole) and four degradation byproducts (phenol, 1-methylbenzotriazole, dimethyl benzylamine, and carbazole) under anaerobic conditions.

\section{Environmental evidence}

Table 6 summarizes the major studies on BT concentrations in different environmental matrices. WWTP effluents are important source of BTs and important direct impact is due to deicing activities. BT was detected in water and soil samples from airports, especially during the deicing season; concentrations are greatest just after the spring snowmelt (Loos et al. 2010; Breedveld et al. 2002; Heeb et al. 2012).

\section{BTs in soil and sediments}

Few data are available on BT soil and sediment contamination; the ranges of concentration are 3.1-1700 and 0.4-13, $000 \mu \mathrm{g} / \mathrm{kg}$, respectively. McNeill and Cancilla (2009) investigated soils at three different US airports, but BT was detected just in one sample $(4.1 \mu \mathrm{g} / \mathrm{kg}$ d.w.). In the old Oslo airport (Fornebu) (Breedveld et al. 2002), BT was detected in 19 out of 20 topsoil samples beside the runway, with an average concentration of $0.33 \mathrm{mg} / \mathrm{kg}$ d.w. A soil sample taken at $1.2 \mathrm{~m}$ depth had a concentration of $0.51 \mathrm{mg} / \mathrm{kg}$ d.w.

Breedveld et al. (2002) observed high concentrations of BT $(13,000 \mu \mathrm{g} / \mathrm{kg}$ d.w. $)$ in a sediment sample of a small drainage ditch draining the snow disposal site of the Fornebu Oslo airport. BT was detected at the average concentration of $420 \mu \mathrm{g} / \mathrm{kg}$ d.w. in three surface sediment samples and not detected $(<100 \mu \mathrm{g} / \mathrm{kg}$ d.w.) in three other samples collected at a depth of $0.1 \mathrm{~m}$ in the upper organic layer of a wetland area receiving the drainage water from the snow disposal site. Regarding sediment from industrialized areas, Zhang et al. (2011) detected BT just in one sampling location (out of six) at a value of $0.39 \mu \mathrm{g} / \mathrm{kg}$ d.w.; on the contrary, BT was detected in all sediment samples from the Saginaw River and the Detroit River (USA) at values between 0.424 and $33.4 \mu \mathrm{g} / \mathrm{kg}$ d.w.

\section{BTs in groundwater and surface water}

BT concentrations in groundwater range between $<0.001$ and $1100 \mathrm{mg} / \mathrm{m}^{3}$, but the values measured by Breedveld et al. (2002) at the Oslo airports were 3 orders of magnitude higher than the maximum value measured by other authors. Excluding this paper, BT in groundwater ranges between $<0.001$ and $3.242 \mathrm{mg} / \mathrm{m}^{3}$. Breedveld et al. (2002) detected concentrations of BT between 1.2 and $1100 \mathrm{mg} / \mathrm{m}^{3}$ and between 0.11 and $20 \mathrm{mg} / \mathrm{m}^{3}$ in groundwater samples from the old (Fornebu) and new (Gardermoen) Oslo airports, respectively. Groundwater samples were taken from the snow disposal site, the drainage ditch, the deicing pad, and the regeneration plant of aircraft deicing/anti-icing fluids. The highest values were measured in groundwater samples from the sand and gravel deposits that were used to backfill the deicing pad during construction. The areas with the original peat and clay deposits had the lowest BT values.

Loos et al. (2010) performed a survey at European scale; BT was detected in $53 \%$ groundwater samples collected at contaminated sites. The maximum concentration was of $1.032 \mathrm{mg} / \mathrm{m}^{3}$ and the average of $0.024 \mathrm{mg} / \mathrm{m}^{3}$. Kahle et al. (2009) detected BT in four out of six groundwater pumping stations located in a densely populated area of the Canton of Zurich (Switzerland); the detection occurred in the aquifers affected by significant water infiltration from rivers receiving considerable discharge from WWTPs. Reh et al. (2013) measured significant BT concentrations in 67 out of 163 
Table 6 BTs concentration in various environmental matrices

\begin{tabular}{|c|c|c|c|}
\hline Reference & Location & Units & Value \\
\hline \multicolumn{4}{|l|}{ Soils } \\
\hline Breedveld et al. (2002) & Oslo Airport, Fornebu, Norway & $\mu \mathrm{g} / \mathrm{kg}$ d.w. & $\begin{array}{l}100-1700 \\
\text { Mean } 500\end{array}$ \\
\hline McNeill and Cancilla (2009) & Three USA airports & $\mu \mathrm{g} / \mathrm{kg}$ d.w. & $<3.1-4.1$ \\
\hline \multicolumn{4}{|l|}{ Sediments } \\
\hline Breedveld et al. (2002) & Oslo Airport, Fornebu, Norway & $\mu \mathrm{g} / \mathrm{kg}$ d.w. & $\begin{array}{l}<100-13,000 \\
\text { Mean } 4500\end{array}$ \\
\hline \multirow[t]{2}{*}{ Zhang et al. (2011) } & Songhua River, China & $\mu \mathrm{g} / \mathrm{kg}$ d.w. & 0.385 \\
\hline & Saginaw and Detroit rivers, USA & $\mu \mathrm{g} / \mathrm{kg}$ d.w. & $\begin{array}{l}0.424-33.4 \\
\text { Mean } 9.43\end{array}$ \\
\hline \multicolumn{4}{|l|}{ Groundwater } \\
\hline \multirow[t]{2}{*}{ Breedveld et al. (2002) } & Oslo Airport, Fornebu, Norway & $\mathrm{mg} / \mathrm{m}^{3}$ & $\begin{array}{l}1.2-1100 \\
\text { Mean } 371\end{array}$ \\
\hline & Oslo Airport, Gardermoen, Norway & $\mathrm{mg} / \mathrm{m}^{3}$ & $\begin{array}{l}0.11-20 \\
\text { Mean } 4.75\end{array}$ \\
\hline Kahle et al. (2009) & Canton of Zurich, Switzerland & $\mathrm{mg} / \mathrm{m}^{3}$ & $\begin{array}{l}0.016-0.077 \\
\text { Mean } 0.047\end{array}$ \\
\hline Loos et al. (2010) & Europe & $\mathrm{mg} / \mathrm{m}^{3}$ & $\begin{array}{l}<0.001-1.032 \\
\text { Mean } 0.024\end{array}$ \\
\hline Liu et al. (2011b) & $\begin{array}{l}\text { Next to a wastewater treatment plant, } \\
\text { Adelaide, Australia }\end{array}$ & $\mathrm{mg} / \mathrm{m}^{3}$ & $0.280 \pm 0.018$ \\
\hline Reh et al. 2013 & Karstified aquifer, Germany & $\mathrm{mg} / \mathrm{m}^{3}$ & $\begin{array}{l}0.0049-3.2418 \\
\text { Median } 0.0434\end{array}$ \\
\hline \multicolumn{4}{|l|}{ Surface Water } \\
\hline Breedveld et al. (2002) & Oslo Airport, Fornebu, Norway & $\mathrm{mg} / \mathrm{m}^{3}$ & $\begin{array}{l}1.5-33 \\
\text { Mean } 9.0\end{array}$ \\
\hline Weiss and Reemtsma (2005) & Lake Tegel, Berlin region, Germany & $\mathrm{mg} / \mathrm{m}^{3}$ & 0.9 \\
\hline \multirow[t]{2}{*}{ Giger et al. (2006) } & Rivers in Zurich District, Switzerland & $\mathrm{mg} / \mathrm{m}^{3}$ & $\begin{array}{l}0.06-6.3 \\
\text { Mean } 0.94\end{array}$ \\
\hline & Lake in Zurich District, Switzerland & $\mathrm{mg} / \mathrm{m}^{3}$ & $\begin{array}{l}0.02-1.2 \\
\text { Mean } 0.55\end{array}$ \\
\hline Vousta et al. (2006) & Glatt river, Switzerland & $\mathrm{mg} / \mathrm{m}^{3}$ & $0.636-3.69$ \\
\hline Kahle et al. (2009) & Lakes in the Midland region, Switzerland & $\mathrm{mg} / \mathrm{m}^{3}$ & $\begin{array}{l}0.011-0.917 \\
\text { Mean } 0.211\end{array}$ \\
\hline Kiss and Fries (2009) & Main, Hengstbach, and Hegbach rivers, Germany & $\mathrm{mg} / \mathrm{m}^{3}$ & $\begin{array}{l}0.038-1.47 \\
\text { Mean } 0.35\end{array}$ \\
\hline \multirow[t]{2}{*}{ Nodler et al. (2011) } & Leine River, upstream of a wastewater treatment plant, Germany & $\mathrm{mg} / \mathrm{m}^{3}$ & $\begin{array}{l}0.034-0.176 \\
\text { Mean } 0.095\end{array}$ \\
\hline & Leine River, downstream of a wastewater treatment plant, Germany & $\mathrm{mg} / \mathrm{m}^{3}$ & $\begin{array}{l}0.248-0.845 \\
\text { Mean } 0.510\end{array}$ \\
\hline Heeb et al. (2012) & Haihe River, China & $\mathrm{mg} / \mathrm{m}^{3}$ & $\begin{array}{l}0.5-4.5 \\
\text { Median } 1.09\end{array}$ \\
\hline Esteban et al. (2014) & Manzanares and Jarama rivers, Spain & $\mathrm{mg} / \mathrm{m}^{3}$ & $0.097-1.184$ \\
\hline
\end{tabular}

groundwater samples collected from a karstified aquifer in Germany under an urban area of about $65 \mathrm{~km}^{2}$; this area was characterized by intensive industrial activities and several waste disposal sites.

In South Australia, Liu et al. (2011b) measured four BTs in groundwater collected near a WWTP, and BT was at a concentration of $0.280 \pm 0.0175 \mathrm{mg} / \mathrm{m}^{3}$. The presence of the BTs in groundwater was expected due to pumping of WWTP effluents into aquifer for water reuse scheme. Often BTs were detected both in surface water and in aquifer system; in this cases, it seemed that BTs were partially eliminated through soil and subsurface passage (Kahle et al. 2009).

The concentrations of BT in surface water are reported between 0.011 and $33 \mathrm{mg} / \mathrm{m}^{3}$. Breedveld et al. (2002) 
Table 7 Orders of magnitude of concentrations reported in the literature for the investigated pollutants in the different environmental matrices and food

\begin{tabular}{llll}
\hline Pollutant & Soils and sediments $(\mu \mathrm{g} / \mathrm{kg}$ d.w. $)$ & Groundwater and surface water $\left(\mathrm{mg} / \mathrm{m}^{3}\right)$ & Foodstuff $(\mu \mathrm{k} / \mathrm{kg}$ f.w. $)$ \\
\hline BPA & $10^{-1}-10^{2}$ & $10^{-3}-10^{2}$ & $10^{-1}-10^{3}$ \\
NP & $10^{-2}-10^{4}$ & $10^{-3}-10$ & $10^{-1}-10^{3}$ \\
BPs & $10^{-1}-10^{2}$ & $10^{-3}-10$ & $10^{-1}-10$ \\
BTs & $10^{-1}-10^{4}$ & $10^{-3}-10^{3}$ & - \\
\hline
\end{tabular}

measured concentrations of BT between 1.5 and $33 \mathrm{mg} / \mathrm{m}^{3}$ in samples collected in the area of the Fornebu Oslo airport. Giger et al. (2006) and Vousta et al. (2006) investigated the
Glatt River and its valley, a densely populated region of $260 \mathrm{~km}^{2}$ with 240,000 inhabitants in the northeastern part of Switzerland. The Glatt River catchment included the northern

Table 8 Available environmental quality standards for pollutants of concern in the investigated environmental matrices

\begin{tabular}{|c|c|c|c|}
\hline Reference & Description & Units & Value \\
\hline \multicolumn{4}{|l|}{ BPA—soils and sediments } \\
\hline BCLAWS (2014) & Soil—standard, agricultural, urban park, residential soil (Canada) & $\mathrm{mg} / \mathrm{kg}$ d.w. & 3100 \\
\hline BCLAWS (2014) & Soil—standard, commercial, industrial soil (Canada) & $\mathrm{mg} / \mathrm{kg}$ d.w. & 31,000 \\
\hline USEPA (2014b) & Soil—regional screening level, residential soil (USA) & $\mathrm{mg} / \mathrm{kg}$ d.w. & 310 \\
\hline USEPA (2014b) & Soil—regional screening level, industrial soil (USA) & $\mathrm{mg} / \mathrm{kg}$ d.w. & 4100 \\
\hline \multicolumn{4}{|l|}{ BPA-waters } \\
\hline CMEE (1994) & Surface water - proposed water quality objective (Canada) & $\mathrm{mg} / \mathrm{m}^{3}$ & 5 \\
\hline BCLAWS (2014) & Drinking water — standard (Canada) & $\mathrm{mg} / \mathrm{m}^{3}$ & 1800 \\
\hline USEPA (2014b) & Water-regional screening level, tapwater (USA) & $\mathrm{mg} / \mathrm{m}^{3}$ & 77 \\
\hline \multicolumn{4}{|l|}{$\mathrm{NP}$ - soils and sediments } \\
\hline DanishEPA (2000) & Soil—proposed quality criteria (Denmark) & $\mathrm{mg} / \mathrm{kg}$ d.w. & 25 \\
\hline $\begin{array}{l}\text { CCME (2002); } \\
\text { Alberta (2014) }\end{array}$ & Soil—quality guidelines, residential, agricultural soil (Canada) & $\mathrm{mg} / \mathrm{kg}$ d.w. & 5.7 \\
\hline $\begin{array}{l}\text { CCME (2002); } \\
\text { Alberta (2014) }\end{array}$ & Soil—quality guidelines, commercial, industrial soil (Canada) & $\mathrm{mg} / \mathrm{kg}$ d.w. & 14 \\
\hline ISS (2011) & Soil—proposed limit for residential soil (Italy) & $\mathrm{mg} / \mathrm{kg}$ d.w. & 0.05 \\
\hline ISS (2011) & Soil—proposed limit for commercial, industrial soil (Italy) & $\mathrm{mg} / \mathrm{kg}$ d.w. & 12.5 \\
\hline CCME (2002) & Sediment — quality guidelines (Canada) & $\mathrm{mg} / \mathrm{kg}$ d.w. & 1.4 \\
\hline CIRCABC (2005) & Sediment — proposed quality standard (Europe) & $\mathrm{mg} / \mathrm{kg}$ d.w. & 0.18 \\
\hline \multicolumn{4}{|l|}{$\mathrm{NP}$ - waters } \\
\hline ISS (2011) & Groundwater-proposed limit (Italy) & $\mathrm{mg} / \mathrm{m}^{3}$ & 0.3 \\
\hline Alberta (2014) & Groundwater - tier 1 remediation guidelines (Canada) & $\mathrm{mg} / \mathrm{m}^{3}$ & 6.6 \\
\hline CMEE (1994) & Surface water - proposed water quality objective (Canada) & $\mathrm{mg} / \mathrm{m}^{3}$ & 0.04 \\
\hline EC (2013) & $\begin{array}{l}\text { Surface water-maximum acceptable concentration, } \\
\text { environmental quality standard (Europe) }\end{array}$ & $\mathrm{mg} / \mathrm{m}^{3}$ & 2 \\
\hline European Parliament (2013) & $\begin{array}{l}\text { Surface water - maximum annual average concentration, } \\
\text { environmental quality standard (Europe) }\end{array}$ & $\mathrm{mg} / \mathrm{m}^{3}$ & 0.3 \\
\hline \multicolumn{4}{|l|}{ BPs - soils and sediments } \\
\hline USEPA (2007) & Soil—remediation level Superfund Swannanoa (USA) & $\mathrm{mg} / \mathrm{kg}$ d.w. & 9.3 \\
\hline \multicolumn{4}{|l|}{$\mathrm{BPs}$ - waters } \\
\hline USEPA (2007) & Groundwater-remediation level Superfund Swannanoa (USA) & $\mathrm{mg} / \mathrm{m}^{3}$ & 152 \\
\hline \multicolumn{4}{|l|}{ BTs - soils and sediments } \\
\hline \multicolumn{4}{|c|}{ No value available in the literature } \\
\hline \multicolumn{4}{|l|}{ BTs - waters } \\
\hline Kase et al. (2011) & $\begin{array}{l}\text { Surface water-proposed maximum acceptable concentration, } \\
\text { environmental quality standard }\end{array}$ & $\mathrm{mg} / \mathrm{m}^{3}$ & 120 \\
\hline Kase et al. (2011) & $\begin{array}{l}\text { Surface water-proposed maximum annual average } \\
\text { concentration, environmental quality standard }\end{array}$ & $\mathrm{mg} / \mathrm{m}^{3}$ & 30 \\
\hline
\end{tabular}


part of the city of Zurich; ten municipal wastewater treatment plants discharged their final effluents into the river. Furthermore, the international airport of Zurich was located on the east of the Glatt River. Similar values were found in the two studies (0.06$6.3 \mathrm{mg} / \mathrm{m}^{3}$ in Giger et al. (2006) and $0.636-3.69 \mathrm{mg} / \mathrm{m}^{3}$ in Vousta et al. (2006)). The mass balance clearly indicated the input from the Zurich airport ( $28 \%$ of the total BT load), where BT was used as an anticorrosive component. Giger et al. (2006) also analyzed waters from three prealpine lakes in the Canton of Zurich (Greifensee, Zurich, and Geneva). Greifensee lake is located northeast of Zurich and outflows into the Glatt River; a population of about 100,000 inhabitants live in the catchment discharging to the Greifensee. Eight municipal WWTPs discharged their treated effluents into Lake Zurich, while Lake Geneva received wastewaters from Lausanne City. BT concentrations measured in the three lakes were $0.9-1.1,0.12-0.4$, and $0.18-0.2 \mathrm{mg} / \mathrm{m}^{3}$, respectively. Kahle et al. (2009) measured BT concentration in water samples from eight lakes of the Swiss Midland region at values between 0.11 and $0.917 \mathrm{mg} / \mathrm{m}^{3}$; the BT concentrations indicate that this compound, regularly discharged to surface waters, was suitable quantitative markers of domestic wastewater in surface waters. Nodler et al. (2011) measured an increase of BT of 1 order of magnitude between water samples collected upstream $\left(0.034-0.0176 \mathrm{mg} / \mathrm{m}^{3}\right)$ and downstream $\left(0.248-0.845 \mathrm{mg} / \mathrm{m}^{3}\right)$ of the WWTP discharge in the Leine River (Germany). Kiss and Fries (2009) assessed the occurrence of BT in three German rivers (Main, Hengstbach, and Hegbach). Main and Hengstbach rivers received effluents from domestic WWTPs and were influenced by the Frankfurt International Airport; the concentrations ranged between 0.025 and $1.474 \mathrm{mg} / \mathrm{m}^{3}$. Due to the absence of wastewater effluents in the Hegbach River, a significant concentration $\left(0.038 \mathrm{mg} / \mathrm{m}^{3}\right)$ was observed just in one sample. In surface water samples of Spain, BT hot spots were found with a maximum concentration of $1184 \mu \mathrm{g} / \mathrm{m}^{3}$ in Manzanares River, $345 \mu \mathrm{g} / \mathrm{m}^{3}$ in Jarama River, and $1120 \mu \mathrm{g} / \mathrm{m}^{3}$ in Ter River (Esteban et al. 2014). Heeb et al. (2012) investigated the $175 \mathrm{~km}$ stretch of the Wenyu River and the North Canal from Beijing to Tianjin (China), resulting in BT concentrations between 0.5 and $4.5 \mathrm{mg} / \mathrm{m}^{3}$. Wastewaters from industrial areas and from the Beijing International Airport were the most probable sources of pollution.

\section{Conclusions}

The CECs discussed in this review are widespread in the environment due to consistent industrial production and persistence. Table 7 summarizes the concentration orders of magnitude reported in the literature for the different environmental matrices and foodstuff; Table 8 resumes the environmental quality standards worldwide for the pollutants of concern available in the literature. By comparing the environmental quality standards in Table 8 with the ranges in Table 7, BPA levels in soils and sediments are not critical, even if the lowest value proposed for BPA in solid matrix $(310 \mathrm{mg} / \mathrm{kg}$, residential soil USA) is considered, as the maximum reported values are somewhat 3 orders of magnitude lower. However, in the future, it is possible that more stringent limits are defined. The Canadian water quality objective of $5 \mathrm{mg} / \mathrm{m}^{3}$ is quite stringent as in several situations up to an order of magnitude, and higher concentrations have been reported in the literature. For the NP, rigorous limits have been set by the European Commission. In Italy also, provisional limits $50 \mu \mathrm{g} / \mathrm{kg}$ for residential soil and $0.3 \mathrm{mg} / \mathrm{m}^{3}$ for groundwater exist. A more stringent water quality standard of $0.04 \mathrm{mg} / \mathrm{m}^{3}$ was proposed in Canada. As the widespread presence of NP at high levels in the various media is reported, it seems quite important to continue and intensify environmental monitoring. For BPs and BTs, the proposed standards are few; therefore, further studies are necessary for defining useful screening values to compare with. At present, the worldwide measured concentrations of BPs reported in the literature are in compliance with the values proposed for BPs by USEPA in 2007 (9.3 mg/kg for soil and $152 \mathrm{mg} / \mathrm{m}^{3}$ for groundwater). Finally, significant standards for BTs were not reported in the literature; the value of $30 \mathrm{mg} / \mathrm{m}^{3}$ proposed for surface water is about 2 orders of magnitude lower than the maximum BT concentrations. As for foodstuff and drinking water, the range of BPA concentrations in water fulfills the proposed limit for drinking water $\left(100 \mathrm{mg} / \mathrm{m}^{3}\right)$ (Willhite et al. 2008). The concentration of BPA in food is significant, especially in canned food, but the estimated daily intake via food consumption does not exceed the proposed RfD for oral exposure of $10 \mu \mathrm{g} / \mathrm{kg} /$ day (Rykowska and Wasiak 2006). In general, the concentration of $\mathrm{NP}$ in water does not pose risk to human health, but some values exceed the proposed limits by USEPA for acute exposure $\left(6.6 \mathrm{mg} / \mathrm{m}^{3}\right)$ and for chronic exposure $\left(0.7-1.7 \mathrm{mg} / \mathrm{m}^{3}\right)$ (USEPA 2010b). NP concentrations should be monitored in the output stream of treatment plants. High NP concentrations in food have been measured, in particular in edible fish, but in general, these values do not exceed the proposed RfD for oral exposure $(100 \mu \mathrm{g} / \mathrm{kg} /$ day) or Danish TDI $(5 \mu \mathrm{g} / \mathrm{kg} /$ day) (Bakke 2003). No concentration limits or guidelines have been proposed for BPs and BTs in the different environmental matrices. More investigation on the occurrence of BPs in food should be useful to exclude exceeding the proposed RfD for oral exposure $(10 \mu \mathrm{g} / \mathrm{kg} /$ day $)$ and the concentration limit in food $(0.6 \mathrm{mg} / \mathrm{kg}$ f.w.), although the daily intake might be heavily increased by dermal sorption from cosmetics (Jeon et al. 2006; IARC 2010). Particular attention should be paid to BTs because of the high values measured in soils and sediments that might lead to exceed the proposed RfD for inhalation and dermal contact ( $30 \mu \mathrm{g} / \mathrm{kg} /$ day) (Giger et al. 2006).

Further research should be carried out on these CECs. Treatment technologies for waters have to improve the removal efficiency of BPA and NP in order to reduce their discharge 
in water bodies from wastewater treatment plants. More investigation should be carried out to assess the presence and distribution of all these CECs in soils and of BPs and BTs in both surface water and groundwater. Specific studies should be carried out about possible pollution of soils due to the use of biosolids and/or treated wastewater in agriculture practices, in particular to understand the transport of CECs in the edible parts of plants and the risk for humans due to their consumption. The packaging composition for foodstuff should be reformulated to avoid contamination from BPA, NP, and BPs; moreover, the use of BPs as a flavor additive should be avoided. The knowledge of the toxicology of these compounds should be improved.

Acknowledgments This work was financially supported by the Italian Ministry of Education, University and Research in the National Research Program 2010-2011 "Emerging contaminants in air, soil, and water: from source to the marine environment."

Open Access This article is distributed under the terms of the Creative Commons Attribution License which permits any use, distribution, and reproduction in any medium, provided the original author(s) and the source are credited.

\section{References}

Ahel M, Giger W, Koch M (1994) Behavior of alkylphenol polyethoxylate surfactants in the aquatic environment. 1. Occurrence and transformation in sewage-treatment. Water Res 28: $1131-1142$

Alberta (2014) Alberta Soil and Groundwater Remediation Guidelines. http://esrd.alberta.ca/lands-forests/land-industrial/inspections-andcompliance/alberta-soil-and-groundwater-remediation-guidelines. aspx. Accessed Nov 2014

Anderson PD, Denslow ND, Drewes JE, Olivieri AW, Schlenk D, Scott GI, Snyder SA (2012) Monitoring strategies for chemicals of emerging concern (CECs) in California's aquatic ecosystems-recommendations of a science advisory panel. Technical Report 692. California Water Resources Control Board

Andreozzi R, Caprio V, Insola A, Longo G (1998) Photochemical degradation of benzotriazole in aqueous solution. J Chem Technol Biot 73:93-98

Arias-Estévez M, Lòpez-Periago E, Martìnez-Carballo E, Simal-Gàndara J, Mejuto JC, Garcìa-Rì L (2008) The mobility and degradation of pesticides in soils and the pollution of groundwater resources. Agric Ecosyst Environ 123:247-260

Ávila C, Nivala J, Olsson L, Kassa K, Headley T, Mueller RA, Bayona JM, García J (2014) Emerging organic contaminants in vertical subsurface flow constructed wetlands: influence of media size, loading frequency and use of active aeration. Sci Total Environ 494-495:211-217

Azevedo DA, Lacorte S, Viana P, Barcelo D (2001) Occurrence of nonylphenol and bisphenol A in surface waters from Portugal. J Brazil Chem Soc 12:532-537

Bakke D (2003) Human and ecological risk assessment of nonylphenol polyethoxylate-based (NPE) surfactants in forest service herbicide applications. Technical report. USDA Forest Service. Pacific Southwest Region (Region 5)

Balmer ME, Buser HR, Muller MD, Poiger T (2005) Occurrence of some organic UV filters in wastewater, in surface waters, and in fish from Swiss lakes. Environ Sci Technol 39:953-962

Barón E, Gago-Ferrero P, Gorga M, Rudolph I, Mendoza G, Zapata AM, Díaz-Cruz S, Barra R, Ocampo-Duque W, Páez M, Darbra RM, Eljarrat E, Barceló D (2013) Occurrence of hydrophobic organic pollutants (BFRs and UV-filters) in sediments from South America. Chemosphere 92:309-316

Basheer C, Lee HK, Tan KS (2004) Endocrine disrupting alkylphenols and bisphenol-A in coastal waters and supermarket seafood from Singapore. Mar Pollut Bull 48:1145-1167

BCLAWS (2014). Environmental Management Act CONTAMINATED SITES REGULATION - British Columbia, Canada. http://www.bclaws.ca/civix/document/id/complete/statreg/ 375_96_06\#Schedule4. Accessed Nov 2014

Benitez FJ, Acero JL, Real FJ, Roldan G, Rodriguez E (2013) Photolysis of model emerging contaminants in ultra-pure water: kinetics, byproducts formation and degradation pathways. Water Res 47:870-880

Bennett ER, Metcalfe CD (1997) Distribution of alkylphenol compounds in great lakes sediments, United States and Canada. Environ Toxicol Chem 17(7):1230-1235

Bennie DT, Sullivan CA, Lee HB, Peart TE, Maguire RJ (1997) Occurrence of alkylphenols and alkylphenol mono- and diethoxylates in natural waters of the Laurentian Great Lakes basin and the upper St. Lawrence River. Sci Total Environ 193:263-275

Bester K, Theobald N, Schroder HF (2001) Nonylphenols, nonylphenolethoxylates, linear alkylbenzenesulfonates (LAS) and bis(4chlorophenyl)-sulfone in the German Bight of the North Sea. Chemosphere 45:817-826

Bhhatarai B, Gramatica P (2011) Modelling physico-chemical properties of (benzo)triazoles, and screening for environmental partitioning. Water Res 45:1463-1471

Bi E, Schmidt TC, Haderlein SB (2007) Environmental factors influencing sorption of heterocyclic aromatic compounds to soil. Environ Sci Technol 41:3172-3178

Breedveld GD, Roseth R, Hem L (2002) Triazoles in the terrestrial environment. 20001103-1. Final Report. Norwegian Geotechnical Institute, Oslo, Norway

Brooks AC, Gaskell PN, Maltby LL (2009) Importance of prey and predator feeding behaviors for trophic transfer and secondary poisoning. Environ Sci Technol 43:7916-7923

Brown S, Devin-Clarke D, Doubrava M, O'Connor G (2009) Fate of 4nonylphenol in a biosolids amended soil. Chemosphere 75:549-554

Buser HR, Poiger T, Müller MD (1998) Occurrence and fate of the pharmaceutical drug diclofenac in surface waters: rapid photodegradation in a lake. Environ Sci Technol 33:3449-3456

Cacho JI, Campillo N, Vinas P, Hernandez-Cordoba M (2012) Determination of alkylphenols and phthalate esters in vegetables and migration studies from their packages by means of stir bar sorptive extraction coupled to gas chromatography-mass spectrometry. J Chromatogr A 1241:21-27

Cancilla DA, Baird JC, Rosa R (2003) Detection of aircraft deicing additives in groundwater and soil samples from Fairchild Air Force Base, a small to moderate user of deicing fluids. B Environ Contam Tox 70:868-875

Cao XL, Perez-Locas C, Dufresne G, Clement G, Popovic S, Beraldin F, Dabeka RW, Feeley M (2011) Concentrations of bisphenol A in the composite food samples from the 2008 Canadian total diet study in Quebec City and dietary intake estimates. Food Addit Contam A 28(6):791-798

CCME (2002) Canadian soil quality guidelines for the protection of environmental and human health: nonylphenol and its ethoxylates. In: Canadian environmental quality guidelines, Canadian Council of Ministers of the Environment, Winnipeg 
Cespedes R, Lacorte S, Raldua D, Ginebreda A, Barcelo D, Pina B (2005) Distribution of endocrine disruptors in the Llobregat River basin (Catalonia, NE Spain). Chemosphere 61:1710-1719

Chang BV, Yu CH, Yuan SY (2004) Degradation of nonylphenol by anaerobic microorganisms from river sediment. Chemosphere 55: 493-500

Chang BV, Liu JH, Liao CS (2014) Aerobic degradation of bisphenol-A and its derivatives in river sediment. Environ Technol 35(4):416424

Chefetz B, Mualem T, Ben-Ari J (2008) Sorption and mobility of pharmaceutical compounds in soil irrigated with reclaimed wastewater. Chemosphere 73(8):1335-1343

Chen W, Xu J, Lu S, Jiao W, Wu L, Chang AC (2013) Fates and transport of PPCPs in soil receiving reclaimed water irrigation. Chemosphere 93:2621-2630

Christian T, Schneider R, Farber HA, Skutlarek D, Meyer MT, Goldbach HE (2003) Determination of antibiotic residues in manure, soil, and surface waters. Acta Hydrochim Hydrobiol 31:36-44

CIRCABC (2005). Common Implementation Strategy for the Water Framework Directive, Environmental Quality Standards (EQS) Substance Data Sheet Priority Substance No. 24 4-Nonylphenol (branched) and Nonylphenol, CAS-No. 84852-15-3 and 2515452-3 -Final version Brussels, 31 July 2005 at the CIRCABC server. https://circabc.europa.eu/sd/a/af1b09f2-ff9a-46f6-ba2dd4bc2adfeee0/24_Nonylphenol_EQSdatasheet_310705.pdf. Accessed Dec 2014

CMEE (1994) Canadian Ministry of Environment and Energy. Policies guidelines provincial water quality objectives - Ontario. PIBS 3303E

Cornell JS, Pillard DA, Hernandez MT (2000) Comparative measures of the toxicity of component chemicals in aircraft deicing fluids. Environ Toxicol Chem 19:1465-1472

Corvini PFX, Schäffer A, Schlosser D (2006a) Microbial degradation of nonylphenol and other alkylphenols - our evolving view. Appl Microbiol Biot 72:223-243

Corvini PFX, Hollender J, Ji R, Schumacher S, Prell J, Hommes G, Priefer U, Vinken R, Schäffer A (2006b) The degradation of $\alpha$ quaternary nonylphenol isomers by Sphingomonas sp. strain TTNP3 involves a type II ipso-substitution mechanism. Appl Microbiol Biot 70:114-122

DanishEPA (2000) Toxicological evaluation and limit values for nonylphenol, nonylphenol ethoxylates, tricresyl, phosphates and benzoic acid - Environmental Project no. 5122000 http://www. statensnet.dk/pligtarkiv/fremvis.pl?vaerkid $=6944 \&$ reprid $=0 \&$ filid $=$ 0\&iarkiv $=1$. Accessed Dec 2014

Daughton CG, Ternes TA (1999) Pharmaceuticals and personal care products in the environment: agents of subtle change? Environ Health Perspect 107:907-937

DECOS (2000) 1,2,3-Benzotriazole. 2000/14OSH. Technical report. The Hague: Health Council of the Netherlands, Dutch Expert Committee on Occupational Standards

Diehl J, Johnson SE, Xia K, West A, Tomanek L (2012) The distribution of 4-nonylphenol in marine organisms of North American Pacific Coast estuaries. Chemosphere 87(5):290-297

Ding H, Li Y, Hou J, Wang Q, Wu Y (2014) Sorption behavior and modeling of endocrine-disrupting chemicals on natural sediments: role of biofilm covered on surface. Environ SciPollut Res. doi:10. 1007/s11356-014-3449-8

Dodder NG, Maruya KA, Ferguson PL, Grace R, Klosterhaus S, La Guardia MJ, Lauenstein GG, Ramirez J (2014) Occurrence of emerging contaminants of emerging concern in mussels (Mytilus spp.) along the California coast, and the influence of land use, storm water discharge, and treated wastewater effluent. MarPollut Bull 81: 340-346

Dodgen LK, Li J, Parker D, Gan JJ (2013) Uptake and accumulation of four PPCP/EDCs in two leafy vegetables. Environ Pollut 182:150-156
Dodgen LK, Li J, Wu X, Lu Z, Gan JJ (2014) Transformation and removal pathways of four common PPCP/EDCs in soil. Environ Pollut 193:29-36

Duan X, Li Y, Li X, Zhang DH, Gao Y (2014) Alkylphenols in surface sediments of the Yellow Sea and East China Sea inner shelf: Occurrence, distribution and fate. Chemosphere 107:265-273

EC (2002) European Union Risk Assessment Report-4-Nonylphenol (branched) and nonylphenol, Volume 10. EUR 20387 EN. European Commission - Joint Research Centre

EC (2003) Directive 2003/53/EC of the European Parliament and the Council of 18 June 2003 amending for the 26th time Council Directive 76/769/EEC relating to restrictions on the marketing and use of certain dangerous substances and preparations (nonylphenol, nonylphenol ethoxylate and cement). Official Journal of the European Union 17.7.2003. L 178/24

EC (2005) Provisional list of monomers and additives notified to European Commission as substances which may be used in the manufacture of plastics or coatings intended to come into contact with foodstuff. SANCO D3/AS D(2005). Technical report. European Commission Health \& Consumer Protection Directorategeneral

EC (2013) Directive 2013/39/EU of the European Parliament and of the Council of 12 August 2013 amending Directives 2000/60/EC and 2008/105/EC as regards priority substances in the field of water policy. Official Journal of the European Union 24.8.2013. L 226/1

ECHA (2014) Nonylphenol and nonylphenol ethoxylates. Technical report. European Chemicals Agency, Committee for Risk Assessment (RAC), Committee for Socio-economic Analysis (SEAC)

Esteban S, Gorga M, Petrovic M, González-Alonso S, Barceló D, Valcárcel Y (2014) Analysis and occurrence of endocrinedisrupting compounds and estrogenic activity in the surface waters of Central Spain. Sci Total Environ 466-467:939-951

EUGRIS (2013) Portal for soil and water management in Europe. Emerging pollutants. http://www.eugris.info/FurtherDescription. asp? $\mathrm{Ca}=2 \& \mathrm{Cy}=0 \& \mathrm{~T}=$ Emerging\%20Pollutants \&e=95. Accessed May 2014

Félix-Cañedo TE, Durán-Álvarez JC, Jiménez-Cisneros B (2013) The occurrence and distribution of a group of organic micropollutants in Mexico City's water sources. Sci Total Environ 454-455:109-118

Fent G, Hein W, Moendel M, Kubiak R (2003) Fate of 14C-bisphenol A in soils. Chemosphere 51:735-746

Fent K, Zenker A, Rapp M (2010) Widespread occurrence of estrogenic UV-filters in aquatic ecosystems in Switzerland. Environ Pollut 158: $1817-1824$

Ferrara F, Fabietti F, Delise M, Funari E (2005) Alkylphenols and alkylphenol ethoxylates contamination of crustaceans and fishes from the Adriatic Sea (Italy). Chemosphere 59:11451150

Ferrara F, Ademollo N, Delise M, Fabietti F, Funari E (2008) Alkylphenols and their ethoxylates in seafood from the Tyrrhenian Sea. Chemosphere 72:1279-1285

Flint S, Markle T, Thompson S, Wallace E (2012) Bisphenol A exposure, effects and policy: a wildlife perspective. J Environ Manage 104: 19-34

Focazio MJ, Kolpin DW, Barnes KK, Furlong ET, Meyer MT, Zaugg SD, Barber LB, Thurman EM (2008) A national reconnaissance of pharmaceuticals and other organic wastewater contaminants in the United States-II. Untreated drinking water sources. Sci Total Environ 402(2-3):201-216

Fries E, Puttmann W (2003) Occurrence and behaviour of 4-nonylphenol in river water of Germany. J Environ Monit 5:598-603

Fu M, Li Z, Gao H (2007) Distribution characteristics of nonylphenol in Jiaozhou Bay of Qingdao and its adjacent rivers. Chemosphere 69: 1009-1016 
Fujii K, Kituchi S (2005) Degradation of benzophenone, a potential xenoestrogen, by a yeast isolated from the activated sludge of a sewage treatment plant in Hokkaido. World J Microb Biot 21:1311-1315

Gabriel F, Routledge E, Heidlberger A, Rentsch D, Guenther K, Giger W, Sumpter J, Kohler H (2008) Isomer-specific degradation and endocrine disrupting activity of nonylphenols. Environ Sci Technol 42: 6399-6408

Gago-Ferrero P, Badia-Fabregat M, Olivares A, Piña B, Blánquez P, Vicent T, Caminal G, Díaz-Cruz M, Barceló D (2012) Evaluation of fungal- and photo-degradation as potential treatments for the removal of sunscreens BP3 and BP1. Sci Total Environ 427-428: 355-363

Gago-Ferrero P, Diaz-Cruz MS, Barcelo D (2013) Multi-residue method for trace level determination of UV filters in fish based on pressurized liquid extraction and liquid chromatography quadrupole-linear ion trap-mass spectrometry. J Chromatogr A 1286:93-101

Gao JA, Pedersen JA (2005) Adsorption of sulfonamide antimicrobial agents to clay minerals. Environ Sci Technol 39(24):9509-9516

Gibson R, Durán-Álvarez J, León Estrada K, Chávez A, Jiménez Cisneros B (2010) Accumulation and leaching potential of some pharmaceuticals and potential endocrine disruptors in soils irrigated with wastewater in the Tula Valley, Mexico. Chemosphere 81:1437-1445

Giger W, Schaffner C, Petere H, Kohler H-P (2006) Benzotriazole and tolyltriazole as aquatic contaminants. Input and occurrence in rivers and lakes. Environ Sci Technol 40:7186-7192

Godejohann M, Heintz L, Daolio C, Berset J, Muff D (2009) Comprehensive non-targeted analysis of contaminated groundwater of a former ammunition destruction site using 1H-NMR and HPLCSPE-NMR/TOF-MS. Environ Sci Technol 43:7055-7061

Gong J, Yang Y, Chen DY, Ran Y (2011) Sequential ASE extraction of alkylphenols from sediments: occurrence and environmental implications. J Hazard Mater 192:643-650

Gorga M, Insa S, Petrovic M, Barceló D (2014) Analysis of endocrine disrupters and related compounds in sediment sand sewage sludge using on-line turbulent flow chromatography-liquid chromatography-tandem mass spectrometry. J Chromatogr A 1352:29-37

Gorga M, Insa S, Petrovic M, Barceló D (2015) Occurrence and spatial distribution of EDCs and related compounds in waters and sediments of Iberian rivers. Sci Total Environ 503-504: 69-86

Grabicova K, Fedorova G, Burkina V, Steinbach C, Schmidt-Posthaus H, Zlabek V, Kroupova HK, Grabic R, Randak T (2013) Presence of UV filters in surface water and the effects of phenylbenzimidazole sulfonic acid on rainbow trout (Oncorhynchus mykiss) following a chronic toxicity test. Ecotox Environ Safe 96:41-47

Guenther K, Heinke V, Thiele B, Kleist E, Prast H, Raecker T (2002) Endocrine disrupting nonylphenols are ubiquitous in food. Environ Sci Technol 36:1676-1680

Guidechem (2013) Oxybenzone. http://www.guidechem.com/reference/ dic-2893.html Accessed May 2014

Gyllenhammar I, Glynn A, Darnerud PO, Lignell S, van Delft R, Aune M (2012) 4-Nonylphenol and bisphenol A in Swedish food and exposure in Swedish nursing women. Environ Int 43:21-28

Harris C, Routledge E, Schaffner C, Brian J, Giger W, Sumpter J (2007) Benzotrialole is antiestrogenic in vitro but not in vivo. Environ Toxicol Chem 26(11):2367-2372

Hart DS, Davis LC, Erickson LE, Callender TM (2004) Sorption and partitioning parameters of benzotriazole compounds. Microchem J 77:9-17

Hayashi T, Okamoto Y, Ueda K, Kojima N (2006) Formation of estrogenic products from benzophenone after exposure to sunlight. Toxicol Lett 167:1-7

Heeb F, Singer H, Pernet-Coudrier B, Qi W, Liu H, Longree P, Muller B, Berg M (2012) Organic micropollutants in rivers downstream of the megacity Beijing: sources and mass fluxes in a large-scale wastewater irrigation system. Environ Sci Technol 46:8680-8688
Heemken OP, Reincke H, Stachel B, Theobald N (2001) The occurrence of xenoestrogens in the Elbe river and the North Sea. Chemosphere 45(3):245-259

Hem LJ, Hartnik T, Roseth R, Breedveld GD (2003) Photochemical degradation of benzotriazole. J Environ Sci Heal A 38(3):471481

Hogenboom A, Van Leerdam J, Voogt P (2009) Accurate mass screening and identification of emerging contaminants in environmental samples by liquid chromatography-hybrid linear ion trap Orbitrap mass spectrometry. J Chromatogr A 1216:510-519

Hou SG, Sun HW, Gao Y (2006) Sorption of small metabolites of nonylphenol polyethoxylates in single and complex systems on aquatic suspended particulate matter. Chemosphere 63:31-38

Huang YQ, Wong CKC, Zheng JS, Bouwman H, Barra R, Walhlstrom B, Neretin L, Wong MH (2012) Bisphenol A (BPA) in China: a review of sources, environmental levels, and potential human health impacts. Environ Int 42:91-99

IARC (1999) Monographs on the evaluation of carcinogenic risks to humans. Re-evaluation of some organic chemicals, hydrazine and hydrogen peroxide. IARC Monographs vol. 71. International Agency for Research on Cancer, Working Group on the Evaluation of Carcinogenic Risks to Humans, Lyon, France

IARC (2010) Benzophenone. IARC Monographs 101. International Agency for Research on Cancer

ICIS (2007) Nonylphenol. http://www.icis.com/Articles/2007/06/25/ 4503346/nonylphenol.html. Accessed May 2014

Ike M, Chen M, Jin C, Fujita M (2002) Acute toxicity, mutagenicity, and estrogenicity of biodegradation products of bisphenol-A. Environ Toxicol 17(5):457-461

Isobe $\mathrm{T}$, Takada $\mathrm{H}$, Kanai $\mathrm{M}$, Tsutsumi $\mathrm{S}$, Isobe $\mathrm{KO}$, Boonyatumanond R, Zakaria MP (2007) Distribution of polycyclic aromatic hydrocarbons (PAHs) and phenolic endocrine disrupting chemicals in South and Southeast Asian mussels. Env Monit Ass 135:423-440

ISS (2011) Richiesta Parere sulle concentrazioni soglie di contaminazione per le sostanze non normate, riscontrate durante l'esecuzione del piano di caratterizzazione dell'area Chemtura Manifacturing Italy di Pedrelungo (Bg). 48353 AMPP.IA.06 (15/11/2011)

Jeon H, Chung Y, Ryu J (2006) Simultaneous determination of benzophenone-type UV filters in water and soil by gas chromatography-mass spectrometry. J Chromatogr A 1131:192-202

Jia Y, Bakken L, Breedveld G, Aagaard P, Frosteg A (2006) Organic compounds that reach subsoil may threaten groundwater quality; effect of benzotriazole on degradation kinetics and microbial community composition. Soil Biol Biochem 38:2543-2556

Jonkers N, Laane R, De Voogt P (2003) Fate of nonylphenol ethoxylates and their metabolites in two Dutch estuaries: evidence of biodegradation in the field. Environ Sci Technol 37:321-327

Jurado A, Gago-Ferrero P, Vàzquez-Suné E, Carrera J, Pujades E, DíazCruz MS, Barceló D (2014) Urban groundwater contamination by residues of UV filters. J Hazard Mater 271:141-149

Kahle M, Buerge IJ, Muller MD, Poiger T (2009) Hydrophilic anthropogenic markers for quantification of wastewater contamination in ground- and surface waters. Environ Toxicol Chem 28(12):25282536

Kalmykova Y, Björklund K, Strömvall AM, Blom L (2013) Partitioning of polycyclic aromatic hydrocarbons, alkylphenols, bisphenol A and phthalates in landfill leachates and stormwater. Water Res 47:13171328

Kameda Y, Kimura K, Miyazaki M (2011) Occurrence and profiles of organic sun-blocking agents in surface waters and sediments in Japanese rivers and lakes. Environ Pollut 159:1570-1576

Kannan K, Keith TL, Naylor CG, Staples CA, Snyder SA, Giesy JP (2003) Nonylphenol and nonylphenol ethoxylates in fish, sediment, and water from the Kalamazoo River, Michigan. Arch Environ Con Tox 44:77-82 
Kase R, Eggen RIL, Junghans M, Gotz C, Juliane H (2011) Assessment of micropollutants from municipal wastewater-combination of exposure and ecotoxicological effect data for Switzerland. In: Einschlag FSG (ed) Waste water-evaluation and management. InTech, Rijeka, pp 31-54

Kasprzyk-Hordern B, Dinsdale RM, Guwy AJ (2008) The occurrence of pharmaceuticals, personal care products, endocrine disruptors and illicit drugs in surface water in South Wales, UK. Water Res 42: 3498-3518

Kawahata H, Ohta H, Inoue M, Suzuki A (2004) Endocrine disruptor nonylphenol and bisphenol A contamination in Okinawa and Ishigaki Islands, Japan-within coral reefs and adjacent river mouths. Chemosphere 55:1519-1527

Kibbey TCG, Paruchuri R, Sabatini DA, Chen L (2007) Adsorption of beta-blockers to environmental surfaces. Environ Sci Technol 41: 5349-5356

Kim S, Choi K (2014) Occurrences, toxicities, and ecological risks of benzophenone-3, a common component of organic sunscreen products: a mini-review. Environ Int 70:143-157

Kimura K, Hara H, Watanabe Y (2007) Elimination of selected acidic pharmaceuticals from municipal wastewater by an activated sludge system and membrane bioreactors. Environ Sci Technol 41:3708-3714

Kinney CA, Furlong ET, Zaugg SD, Burkhard MR, Werner SL, Cahill JD, Jorgensen GR (2006) Survey of organic wastewater contaminants in biosolids destined for land application. Environ Sci Technol 40(23):7207-7215

Kinney CA, Furlong ET, Kolpin DW, Burkhardt MR, Zaugg SD, Werner SL, Bossio JP, Benotti MJ (2008) Bioaccumulation of pharmaceuticals and other anthropogenic waste indicators in earthworms from agricultural soil amended with biosolid or swine manure. Environ Sci Technol 42:1863-1870

Kiss A, Fries EF (2009) Occurrence of benzotriazoles in the rivers main, Hengstbach, and Hegbach (Germany). Environ Sci Pollut R 16: 702-710

Klosterhaus S, Grace R, Hamilton MC, Yee D (2013) Method validation and reconnaissance of pharmaceuticals, personal care products, and alkylphenols in surface waters, sediments, and mussels in an urban estuary. Environ Int 54:92-99

Kolpin DW, Furlong ET, Meyer MT, Thurman EM, Zaugg SD, Barber LB, Buxton HT (2002) Pharmaceuticals, hormones, and other organic wastewater contaminants in U.S. streams 1999-2000: a national reconnaissance. Environ Sci Technol 36:1202-1211

Koniecko I, Staniszewska M, Falkowska L, Burska D, Kielczewska J, Jasinska A (2014) Alkylphenols in surface sediments of the Gulf of Gdansk (Baltic Sea). Water Air Soil Pollut 225:2040

Koschorreck J, Koch C, Rönnefahrtet I (2002) Environmental risk assessment of veterinary medicinal products in the EU-a regulatory perspective. Toxicol Lett 131:117-124

Kueh CSW, Lam JYC (2008) Monitoring of toxic substances in the Hong Kong marine environment. Mar Pollut Bull 57(6):744-757

Kumar K, Singh AK, Chander Y, Gupta SC (2005) Antibiotic use in agriculture and its impact on the terrestrial environment. Adv Agron 87:1-54

La Farré M, Perez S, Kantiani L, Barcelo D (2008) Fate and toxicity of emerging pollutants, their metabolites and transformation products in the aquatic environment. Trac-Trend Anal Chem 27(11)

Lacorte S, Latorre A, Guillamon M, Barcelò D (2002) Nonylphenol, octyphenol, and bisphenol a in groundwaters as a result of agronomic practices. Sci World J 2:1095-1100

Lara-Martin PA, Gomez-Parra A, Barcelo D, Gonzalez-Mazo E (2006) Presence of surfactants and their degradation intermediates in sediment cores and grabs from the Cadiz Bay area. Environ Pollut 144: 483-491

Latorre A, Lacorte S, Barcelo D (2003) Presence of nonylphenol, octyphenol and bisphenol-A in two aquifers close to agricultural, industrial and urban areas. Chemosphere 57:111-116
Lee Ferguson P, Bopp RF, Chillrud SN, Aller RC, Brownawell BJ (2003) Biogeochemistry of nonylphenol ethoxylates in urban estuarine sediments. Environ Sci Technol 37:3499-3506

León Z, Chisvert A, Tarazona I, Salvador A (2010) Solid-phase extraction liquid chromatography-tandem mass spectrometry analytical method for the determination of 2-hydroxy-4-methoxybenzophenone and its metabolites in both human urine and semen. Anal Bioanal Chem 398: 831-843

Li J, Jiang L, Liu X, Lv J (2013a) Adsorption and aerobic biodegradation of four selected endocrine disrupting chemicals in soil water system. Int Biodeter Biodegr 76:3-7

Li Y, Duan X, Li X, Zhang D (2013b) Photodegradation of nonylphenol by simulated sunlight. Mar Pollut Bull 66:47-52

Li Y, Zhang S, Song C, You J (2013c) Determination of Bisphenol A and Alkylphenols in Soft Drinks by High-Performance Liquid Chromatography with Fluorescence Detection. Food Anal Methods 6:1284-1290

Liao X, Zhang C, Yao L, Li J, Liu M, Xu L, Evalde M (2014) Sorption behavior of nonylphenol (NP) on sewage-irrigated soil: kinetic and thermodynamic studies. Sci Total Environ 473-474:530-536

Lin A, Reinhard M (2005) Photodegradation of common environmental pharmaceuticals and estrogens in river water. Environ Toxicol Chem 24(6):1303-1309

Liu YS, Ying GG, Shareef A, Kookana RS (2011a) Biodegradation of three selected benzotriazoles under aerobic and anaerobic conditions. Water Res 45:5005-5014

Liu YS, Ying GG, Shareef A, Kookana RS (2011b) Simultaneous determination of benzotriazoles and ultraviolet filters in ground water, effluent and biosolid samples using gas chromatography-tandem mass spectrometry. J Chromatogr A 1218:5328-5335

Liu YS, Ying GG, Shareef A, Kookana RS (2012a) Biodegradation of the ultraviolet filter benzophenone-3 under different redox conditions. Environ Toxicol Chem 31(2):289-295

Liu YS, Ying GG, Shareef A, Kookana RS (2012b) Occurrence and removal of benzotriazoles and ultraviolet filters in a municipal wastewater treatment plant. Environ Pollut 165:225-232

Loos R, Hanke G, Umlauf G, Eisenreich SJ (2007) LC-MS-MS analysis and occurrence of octyl- and nonylphenol, their ethoxylates and their carboxylates in Belgian and Italian textile industry, waste water treatment plant effluents and surface waters. Chemosphere 66:690-699

Loos R, Locoro G, Comero S, Contini S, Schwesig D, Werres F, Balsaa P, Gans O, Weiss S, Blaha L, Bolchi M, Gawlik B (2010) PanEuropean survey on the occurrence of selected polar organic persistent pollutants in ground water. Water Res 44:4115-4126

Loyo-Rosales JE, Rosales-Rivera GC, Lynch AM, Rice CP, Torrents A (2004) Migration of nonylphenol from plastic containers to water and a milk surrogate. J Agr Food Chem 52:2016-2020

Lu Z, Gan J (2014) Isomer-specific biodegradation of nonylphenol in river sediments and structure-biodegradability relationship. Environ SciTechnol 48:1008-1014

Lu J, Wu J, Stoffella PJ, Wilson PC (2013) Analysis of bisphenol A, nonylphenol, and natural estrogens in vegetables and fruits using gas chromatography-tandem mass spectrometry. J Agr Food Chem 61: 84-89

Luo Y, Guo W, Ngo HH, Nghiem LD, Hai FI, Zhang J, Liang S, Wang XC (2014) A review on the occurrence of micropollutants in the aquatic environment and their fate and removal during wastewater treatment. Sci Total Environ 473-474:619-641

Maggioni S, Balaguer P, Chiozzotto C, Benfenati E (2013) Screening of endocrine-disrupting phenols, herbicides, steroid estrogens, and estrogenicity in drinking water from the waterworks of 35 Italian cities and from PET-bottled mineral water. Environ Sci Pollut Res 20:1649-1660

Martínez-Zapata M, Aristizàbal C, Penuela G (2013) Photodegradation of the endocrine-disrupting chemicals $4 n$-nonylphenol and triclosan by simulated solar UV irradiation in aqueous solutions with $\mathrm{Fe}(\mathrm{III})$ and 
in the absence/presence of humic acids. J Photoch Photobio A 251: 41-49

McNeill KS, Cancilla DA (2009) Detection of triazole deicing additives in soil samples from airports with low, mid, and large volume aircraft deicing activities. B Environ Contam Tox 82(3):265-269

Melo SM, Brito MN (2014) Analysis and occurrence of endocrine disruptors in Brazilian water by HPLC-fluorescence detection. Water Air Soil Pollut 225:1783

Mercea P (2009) Physicochemical processes involved in migration of bisphenol A from polycarbonate. J Appl Polym Sci 112(2):579-593

Michałowicz J (2014) Bisphenol A-sources, toxicity and biotransformation. Env Toxic Pharma 37:738-758

Micic V, Hofmann T (2009) Occurrence and behaviour of selected hydrophobic alkylphenolic compounds in the Danube River. Environ Pollut 157:2759-2768

Micić V, Kruge MA, Hofmann T (2013) Variations of common riverine contaminants in reservoir sediments. Sci Total Environ 458-460: $90-100$

Molnar M, Gruiz K, Hajdu CS, Nagy ZS, Fenyvesi E (2013) Tiered approach for environmental risk assessment of emerging pollutants in aquatic systems. Proceedings, AquaConSoil 2013, 12th International UFZ-Deltares Conference on Groundwater-SoilSystems and Water Resource Management, Barcelona, Spain, April 16-19 2013, session C14

Neamtu M, Frimmel FH (2006) Photodegradation of endocrine disrupting chemical nonylphenol by simulated solar UV-irradiation. Sci Total Environ 369:295-306

Nodler K, Licha T, Fischer S, Wagner B, Sauter M (2011) A case study on the correlation of micro-contaminants and potassium in the Leine River (Germany). Appl Geochem 26:2172-2180

Noonan GO, Ackerman LK, Begley TH (2011) Concentration of bisphenol A in highly consumed canned foods on the U.S. market. J Agr Food Chem 59:7178-7185

NORMAN (2013) Network of reference laboratories for monitoring of emerging environmental pollutants. http://www.norman-network. net/index_php.php?module=public/about_us/home. Accessed May 2014

NTP (2006) Toxicology and carcinogenesis studies of benzophenone (CAS No. 119-61-9) in F344/N rats and B6C3F1 mice (feed studies). NTP TR 533. Technical report. National Toxicology Program, U.S. Department of Health and Human Services. NIH Publication no. 06-4469

OEHHA (2009) Toxicological profile for nonylphenol. Office of Environmental Health Hazard Assessment. California Environmental Protection Agency

Patrolecco L, Capri S, De Angelis S, Pagnotta R, Polesello S, Valsecchi S (2006) Partition of nonylphenol and related compounds among different aquatic compartments in Timber River (Central Italy). Water Air Soil Poll 172:151-166

Pojana G, Jonkers N, Marcomini A (2007) Natural and synthetic endocrine disrupting compounds (EDCs) in water, sediment and biota of a coastal lagoon. Environ Int 33:929-936

Rajendra S.C (2000) NTP technical report on the toxicity studies of benzophenone. Toxicity Report Series Number 61. U.S. Department of Health and Human Services Public Health Service, National Institutes of Health

Reh R, Licha T, Geyer T, Nodler K, Sauter M (2013) Occurrence and spatial distribution of organic micro-pollutants in a complex hydrogeological karst system during low flow and high flow periods, results of a two-year study. Sci Total Environ 443:438-445

Rice CP, Schmitz-Afonso I, Loyo-Rosales JE, Link E, Thoma R, Fay L (2003) Alkylphenol and alkylphenol-ethoxylates in carp, water, and sediment from the Cuyahoga River, Ohio. Environ Sci Technol 37: $3747-3754$

Richardson ML, Bowron JM (1985) The fate of pharmaceutical chemicals in the aquatic environment. J Pharm Pharmacol 37:1-12
Ricking M, Schwarzbauer J, Franke S (2003) Molecular markers of anthropogenic activity in sediments of the Havel and Spree Rivers (Germany). Water Res 37:2607-2617

RIKZ (2001) Chemical study on bisphenol A. RIKZ/2001.027. Technical report. Rijksinstituut voor Kust en Zee, Ministerie van Verkeer en Waterstaat, The Netherlands

Roberts S, Higgins C, McCray J (2014) Sorption of emerging organic wastewater contaminants to four soils. Water 6:10281042

Rodil R, Moeder M, Altenburger R, Schmitt-Jansen M (2009) Photostability and phytotoxicity of selected sunscreen agents and their degradation mixtures in water. Anal Bioanal Chem 395:15131524

Rodil R, Quintana JB, Concha-Grana E, Lopez-Mahia P, MuniateguiLorenzo S, Prada-Rodriguez D (2012) Emerging pollutants in sewage, surface and drinking water in Galicia (NW Spain). Chemosphere 86:1040-1049

Rozalska S, Szewczyk R, Długonski J (2010) Biodegradation of 4-nnonylphenol by the non-ligninolytic filamentous fungus Gliocephalotrichum simplex: a proposal of a metabolic pathway. $\mathrm{J}$ Hazard Mater 180:323-331

Rykowska I, Wasiak (2006) Properties, threats, and methods of analysis of bisphenol A and its derivates. Acta Chromatogr $16: 7-27$

Sánchez-Brunete C, Miguel E, Albero B, Tadeo J (2011) Analysis of salicylate and benzophenone-type UV filters in soils and sediments by simultaneous extraction cleanup and gas chromatography-mass spectrometry. J Chromatogr A 1218:4291-4298

Sekela M, Brewer R, Moyle G, Tuominen T (1999) Occurrence of an environmental estrogen (4-nonylphenol) in sewage treatment plant effluent and the aquatic receiving environment. Water Sci Technol 39(10-11):217-220

Shao B, Han H, Li D, Ma Y, Tu X, Wu Y (2007) Analysis of alkylphenol and bisphenol $\mathrm{A}$ in meat by accelerated solvent extraction and liquid chromatography with tandem mass spectrometry. Food Chem 105: 1236-1241

Shchegolikhina A, Schulz S, Marchner B (2012) Interacting effects of cation saturation and drying, freezing, or aging on the extractability of nonylphenol and phenanthrene from a sandy soil. J Soil Sediment 12:1280-1291

Soares A, Guieysse B, Jefferson B, Cartmell E, Lester JN (2008) Nonylphenol in the environment: a critical review on occurrence, fate, toxicity and treatment in wastewaters. Environ Int 34:10331049

Spivack J, Leib TK, Lobos JH (1994) Novel pathway for bacterial metabolism of bisphenol A, rearrangements and stilbene cleavage in bisphenol A metabolism. J Biol Chem 269:7323-7329

Staples C, Friederich U, Hall T, Klecka G, Mihaich E, Ortego L, Caspers N, Hentges S (2010) Estimating potential risks to terrestrial invertebrates and plants exposed to bisphenol A in soil amended with activated sludge biosolids. Environ Toxicol Chem 29(2):467-475

Stewart M, Olsena G, Hickey WC, Ferreira B, Jelić A, Petrović M, Barcelo D (2014) A survey of emerging contaminants in the estuarine receiving environment around Auckland, New Zealand. Sci Total Environ 468-469:202-210

Stuart ME, Manamsa K, Talbot JC, Crane EJ (2011) Emerging contaminants in groundwater. OR/11/013. British Geological Survey Open Report. Keyworth, Nottingham (UK), 123 pp

Sun C, Leong LP, Barlow PJ, Chan SH, Bloodworth BC (2006) Single laboratory validation of a method for the determination of bisphenol a, bisphenol A diglycidyl ether and its derivatives in canned foods by reversed-phase liquid chromatography. J Chromatogr A 1129: $145-148$

Ternes TA, Bonerz M, Herrmann N, Teiser B, Andersen HR (2007) Irrigation of treated wastewater in Braunschweig, Germany: an 
option to remove pharmaceuticals and musk fragrances. Chemosphere 66:894-904

Thomaidis NS, Asimakopoulos AG, Bletsou AA (2012) Emerging contaminants: a tutorial mini-review. Global NEST J 14(1):72-79

Tolls J (2001) Sorption of veterinary pharmaceuticals in soils: a review. Environ Sci Technol 35(17):3397-3406

Topp E, Starratt A (2000) Rapid mineralization of the endocrinedisrupting chemical 4-nonylphenol in soil. Environ Toxicol Chem 19:313-318

TOXNET (2013a) Toxicology Data Nerwork-benzotriazole. http:// toxnet.nlm.nih.gov/cgi-bin/sis/search/a?dbs+hsdb:@term+@ DOCNO+4143. Accessed May 2014

TOXNET (2013b) Toxicology Data Nerwork-benzophenone. http:// toxnet.nlm.nih.gov/cgi-bin/sis/search/a?dbs+hsdb:@term+@ DOCNO+6809. Accessed May 2014

TOXNET (2014) Toxicology Data Network-2-hydroxy-4methoxybenzophenone. http://toxnet.nlm.nih.gov/cgi-bin/sis/ search2/r?dbs+hsdb:@term+@rn+@rel+131-57-7. Accessed Nov 2014

USEPA (1984) Information review: benzophenone. U.S. Environmental Protection Agency, Washington

USEPA (2007) Second superfund five-year review report Chemtronics Superfund Site Swannanoa, Buncombe County, NC. EPA ID: NCD 095459392

USEPA (2010a) Bisphenol A action plan. U.S. Environmental Protection Agency, Washington

USEPA (2010b) Nonylphenol (NP) and nonylphenol ethoxylates (NPEs) action plan. RIN 200-ZA09. Technical report. U.S. Environmental Protection Agency, Washington, DC

USEPA (2010c) 2-(2'-Hydroxy-3',5'-di-tert-amylphenyl) benzotriazole and phenol, 2-(2H-benzotriazole-2-yl)-6-dodecyl-4-methyl; exemption from the requirement of a tolerance. U.S. Environmental Protection Agency, Washington, DC. Federal Register volume 75 no 159

USEPA (2014a) Persistent organic pollutants: a global issue, a global response. http://www2.epa.gov/international-cooperation/ persistent-organic-pollutants-global-issue-global-response. Accessed Nov 2014

USEPA (2014b). Regional screening level. http://www.epa.gov/ reg3hwmd/risk/human/rb-concentration_table/Generic_Tables/. Accessed Nov 2014

USEPA-IRIS (2014) Bisphenol A. Quickview http://cfpub.epa.gov/ncea/ iris/index.cfm?fuseaction=iris. show Quickview\&substance $n m b r=$ 0356. Accessed Nov 2014.

Vethaak AD, Lahr J, Schrap SM, Belfroid AC, Rijs GBJ, Gerritsen A, de Boer J, Bulder AS, Grinwis GCM, Kuiper RV, Legler J, Murk TAJ, Peijnenburg W, Verhaar HJM, de Voogt P (2005) An integrated assessment of estrogenic contamination and biological effects in the aquatic environment of The Netherlands. Chemosphere 59: $511-524$

Vikelsøe J, Thomsen M, Carlsen L (2002) Phthalates and nonylphenols in profiles of differently dressed soils. Sci Total Environ 296:105-116

Vitali M, Ensabella F, Stella D, Guidotti M (2004) Nonylphenols in freshwaters of the hydrologic system of an Italian district: association with human activities and evaluation of human exposure. Chemosphere 57:1637-1647

Vousta D, Hartmann P, Schaffner C, Giger W (2006) Benzotriazoles, alkylphenols and bisphenol A in municipal wastewaters and in the Glatt River, Switzerland. Environ Sci Pollut R 13(5):333-341

Weber S, Khan S, Hollender J (2005) Human risk assessment of organic contaminants in reclaimed wastewater used for irrigation. In: Khan SJ, Muston MH, Schafer AI (eds) Integrated concepts in water recycling. University of Wollongong, Wollongong, pp 724-735

Wehrhan A, Kasteel R, Simunek J, Groeneweg J, Vereecken H (2007) Transport of sulfadiazine in soil columns - experiments and modeling approaches. J Contam Hydrol 89(1-2):107-135
Weiss S, Reemtsma T (2005) Determination of benzotriazole corrosion inhibitors from aqueous environmental samples by liquid chromatography-electrospray ionization-tandem mass spectrometry. Anal Chem 77(22):7415-7420

Willhite CC, Ball GL, McLellan CJ (2008) Derivation of a bisphenol A oral reference dose (RfD) and drinking-water equivalent concentration. J Toxicol Env Heal B 11(2):69-146

Williams CF, Adamsen FJ (2006) Sorption-desorption of carbamazepine from irrigated soils. J Environ Qual 35:1779-1783

Wolschke H, Xie Z, Moller A, Sturm R, Ebinghaus R (2011) Occurrence, distribution and fluxes of benzotriazoles along the German large river basins into the North Sea. Water Res 45:6259-6266

Wright-Walters M, Volz C, Talbott E, Davis D (2011) An updated weight of evidence approach to the aquatic hazard assessment of bisphenol $\mathrm{A}$ and the derivation a new predicted no effect concentration (Pnec) using a non-parametric methodology. Sci Total Environ 409:676685

Writer JH, Ryan JN, Keefe SH, Barber LB (2012) Fate of 4-nonylphenol and $17 \beta$-estradiol in the Redwood River of Minnesota. Environ Sci Technol 46:860-868

Wu ZB, Zhang Z, Chen SP, He F, Fu GP, Liang W (2007) Nonylphenol and octylphenol in urban eutrophic lakes of the subtropical China. Fresen Environ Bull 16:227-234

Wu M, Wang L, Xu G, Liu N, Tang L, Zheng J, Bu T, Lei B (2013) Seasonal and spatial distribution of 4-tert-octylphenol, 4nonylphenol and bisphenol A in the Huangpu River and its tributaries, Shanghai, China. Environ Monit Assess 185:3149-3161

$\mathrm{Xu} \mathrm{J,} \mathrm{Wu} \mathrm{L,} \mathrm{Chen} \mathrm{W,} \mathrm{Chang} \mathrm{A} \mathrm{(2008)} \mathrm{Simultaneous} \mathrm{determination} \mathrm{of}$ pharmaceuticals, endocrine disrupting compounds and hormone in soils by gas chromatography-mass spectrometry. J Chromatogr A 1202(2):189-195

Xu J, Chen W, Wu L, Green R (2009) Leachability of some emerging contaminants in reclaimed municipal wastewater-irrigated turf grass fields. Environ Toxicol Chem 28(9):1842-1850

Xu EGB, Liu S, Ying GG, Zheng GJS, Lee JHW, Leung MYK (2014) The occurrence and ecological risks of endocrine disrupting chemicals in sewage effluents from three different sewage treatment plants, and in natural seawater from a marine reserve of Hong Kong. Mar Pollut Bull 85:352-362

Xuan R, Blassengale AA, Wang Q (2008) Degradation of estrogenic hormones in a silt loam soil. J Agr Food Chem 56:9152-9158

Yamamoto H, Liljestrand HM (2003) The fate of estrogenic compounds in the aquatic environment: sorption onto organic colloids. Water Sci Technol 47(9):77-84

Yamashita N, Kannan K, Imagawa T, Villeneuve DL, Hashimato S, Miyazaki A, Giesy JP (2000) Vertical profile of polychlorinated dibenzo-p-dioxins, dibenzofurans, naphthalenes, biphenyls, polycyclic aromatic hydrocarbons, and alkylphenols in a sediment core from Tokyo Bay, Japan. Environ Sci Technol 34:35603567

Yang GP, Ding HY, Cao XY, Ding QY (2011) Sorption behavior of nonylphenol on marine sediments: effect of temperature, medium, sediment organic carbon and surfactant. Mar Pollut Bull 62:23622369

Yang Y, Wang Z, Xie S (2014) Aerobic biodegradation of bisphenol A in river sediment and associated bacterial community change. Sci Total Environ 470-471:1184-1188

Ye X, Zhou X, Needham LL, Calafat AM (2011) In-vitro oxidation of bisphenol A: is bisphenol A catechol a suitable biomarker for human exposure to bisphenol A? Anal Bioanal Chem 399:1071-1079

Ying GG, Kookana RS (2003) Degradation of five selected endocrine disrupting chemicals in seawater and marine sediment. Environ Sci Technol 37:1256-1260

Ying G, Kookana R (2005) Sorption and degradation of estrogen-likeendocrine disrupting chemicals in soil. Environ Toxicol Chem 24(10):2640-2645 
Yoon Y, Ryu J, Oh J, Choi BG, Snyder SA (2010) Occurrence of endocrine disrupting compounds, pharmaceuticals, and personal care products in the Han River (Seoul, South Korea). Sci Total Environ 408:636-643

Yu JT, Bouwer EJ, Coelhan M (2006) Occurrence and biodegradability studies of selected pharmaceuticals and personal care products in sewage effluent. Agr Water Manage 86:72-80

Yu L, Fink G, Wintgens T, Melin T, Ternes TA (2009) Sorption behavior of potential organic wastewater indicators with soils. Water Res 43: 951-960

Yu Y, Liu Y, Wu L (2013) Sorption and degradation of pharmaceuticals and personal care products (PPCPs) in soils. Environ Sci Pollut Res 20:4261-4267

Zenker A, Schmutz H, Fent K (2008) Simultaneous trace determination of nine organic UV-absorbing compounds (UV filters) in environmental samples. J Chromatogr A 1202:64-74

Zhan M, Yang X, Xian Q, Kong L (2006) Photosensitized degradation of bisphenol A involving reactive oxygen species in the presence of humic substances. Chemosphere 63:378-386

Zhang C, Zeng G, Yuan L, Yu J, Li J, Huang G, Xi B, Liu H (2007) Aerobic degradation of bisphenol A by Achromobacter xylosoxidans strain B-16 isolated from compost leachate of municipal solid waste. Chemosphere 68:181-190
Zhang Z, Ren N, Li YF, Kunisue T, Gao D, Kannan K (2011) Determination of benzotriazole and benzophenone UV filters in sediment and sewage sludge. Environ Sci Technol 45:3909-3916

Zhang W, Yin K, Chen L (2013a) Bacteria-mediated bisphenol A degradation. Appl Microbiol Biotechnol 97:5681-5689

Zhang T, Sun H, Qin X, Wu Q, Zhang Y, Ma J, Kannan K (2013b) Benzophenone-type UV filters in urine and blood from children, adults, and pregnant women in China: partitioning between blood and urine as well as maternal and fetal cord blood. Sci Total Environ 461-462:49-55

Zhang Y, Meng W, Zhang Y (2014) Occurrence and partitioning of phenolic endocrine-disrupting chemicals (EDCs) between surface water and suspended particulate matter in the North Tai Lake Basin, Eastern China. Bull Environ Contam Toxicol 92:148-153

Zhao J, Li Y, Zhang C, Zeng Q, Zhou Q (2008) Sorption and degradation of bisphenol A by aerobic activated sludge. J Hazard Mater 155: 305-311

Zhou JL, Liu R, Wilding A, Hibberd A (2007) Sorption of selected endocrine disrupting chemicals to different aquatic colloids. Environ Sci Technol 41:206-213

Zwiener C, Frimmel FH (2003) Short-term test with a pilot sewage plant and biofilm reactors for the biological degradation of pharmaceutical compounds clofibric acid, ibuprofen, and diclofenac. Sci Total Environ 309:201-211 